\title{
LAND AND WATER RESOURCES ASSESSMENT FOR SUSTAINABLE AGRICULTURAL DEVELOPMENT IN EL-KHARGA OASES BY USING REMOTE SENSING AND GEOGRAPHIC INFORMATION SYSTEM
}

\author{
M.M. Soliman \\ Soils, water and Environment Res. Ins., Agric. Res. Center. \\ Received: Jan. 8, 2019 \\ Accepted: Mar. 8,2020
}

\begin{abstract}
El-Kharga Oases, New Valley governorate, Egypt was selected as a study area. It is located between latitudes $25^{\circ} 15^{\prime}$ and $26^{\circ} 05^{\prime} \mathrm{N}$. and longitudes $30^{\circ} 05^{\prime}$ and $30^{\circ} 45^{\prime} \mathrm{E}$., having an area of $18813.8 \mathrm{~km}^{2}$. The aim of this investigation is to study the characteristics of soils and groundwater in this area for evaluating their capability and suitability for growing main crops using RS and GIS. The obtained geomorphic map showed that, the area comprises three distinct geomorphic units namely, high land (28.8\%), plateau (39.3\%) and depression floor (31.9\%). The depression floor of various origin and almost flat areas is the main landforms and suitable units for developmental plans. The soils were classified up to sub great group level on the basis of Soil Survey Staff (2014). Land evaluation was conducted using a model depend on the bases of Sys \& Verheye index and land suitability for irrigated agriculture. Accordingly, the current capability of the studied soils was classified as: fair (III) for about $45 \%$ from the studied area, poor IV (about $50 \%$ ) and very poor $\mathbf{N}$ for the remaining area. By executing a suitable improvement practices, these classes could be developed to the following three potential capability classes; good (II), fair (III) and poor (IV). Also, soil suitability for growing specific field, vegetable and fruit crops were evaluated in the studied geomorphic units.

The quality evaluation of ground water resources showed that, the $\mathrm{pH}$ values ranged from ultra-acid (3.47 north El-Kharga) to slightly alkaline (7.83 in Max Qibly). The salinity of ground water changed from 0.48 to $119 \mathrm{dS} \mathrm{m}^{-1}$ indicating non-saline to very extremely saline, TDS values varied from 307.2 to 71424 ppm (fresh, brackish, to extremely saline water). Total hardness varied from soft to very hard.
\end{abstract}

Key words: Geomorphic Units, Remote Sensing (RS), GIS, Soil Taxonomy, Land Evaluation.

\section{INTRODUCTION}

Egypt population is 102 million, which however, settles on just $6.6 \%$ of the Egyptian territory along the flood plain and Nile Delta and the River Nile. The over increase of population has inspired both government and individuals for lateral spread towards the desert land. One of the main targeted areas for lateral expansion are in the Western Desert but at specific localities such as Oases.

The Western Desert of Egypt covers approximately $650.000 \mathrm{~km}^{2}$, which are more than two thirds of the total area of
Egypt. The significant areas in the Western Desert are Siwa, Bahariya, Farafra, Dakhla and Kharga Oases. ElKharga Oases is one of the suggested areas for the horizontal expansion in the Western Desert which has high store of artesian water from multi layers of Nubian sandstone Aquifer System. It is bounded by the Eocene, limestone plateau from the east and north, where steep cliffs form a sharp boundary to the depression floor. El- Kharga Oases area is located between latitudes $25^{\circ} 15^{\circ}$ and $26^{\circ} 05^{\circ}$ North and Longitudes $30^{\circ} 05^{\circ}$ and $30^{\circ} 45^{\circ}$ East. 
(Fig.1). It is bordered on the north and east by a steep disjointed scarp $200 \mathrm{~m}$ high. On the west it opens on to the Dakhla Depression. The Southern boundary is not clear cut, as the depression floor blends gradually into the terrain to the south. Elevation on the floor of the depression range from near 0 (a. s. I.) to $120 \mathrm{~m}$ (a. s. I.). The surface elevation rises gently from the depression to the west up to over 400 m. (a. s. I).

El-Kharga Oases is characterized by a tropical arid climate. The maximum day time temperature fluctuates within a wide range, reaching up to $42 \mathrm{C}^{\circ}$ in summer months, meanwhile in winter, the minimum temperatures may drop as low as zero at night. The annual mean value of relative humidity is about $33.5 \%$. Generally, the atmospheric precipitation extremely scarce and insignificant ( 3.0 $\mathrm{mm}$ /year). Wind speed tends to be low in August. It increases progressively in November to January reaches a peak from March to May cassing dust storms famously known as "El-Khamasin" (CLAC, 2016).

Lithological soil origins of El-Kharga Oases have been studied by Hermina (1990), Said (2000) and Shawna et al (2016). These authors revealed that, ElKharga Oases are occupied by different type of rock varying between Quaternary to Cretaceous areas. It owes its origin to the exposure by erosion of the Nubian sediments which consist of alternation of clays, shales, sands and sandstones. The overlying Cretaceous and Eocene formation which consist essentially of limestone form the plateau which border the Oases from North and East (Fig 2).

The landscape features of El- Kharga Oases were also studied by El - Shazly (1976), Harga (1976), DRI (1983), ASRT (1989) and UNDPI UNECO (2001) using a technique of photo- interpretation and remote sensing, the authors reported that, the Oases consist of three geomorphic units, namely, the elevated plateau, the foothill slopes and the Kharga Oases depression. The latter includes hills, ridges, lacustrine deposits, local marches, crescent sand dunes and sand sheets.

Hydrologically, the only source of water for irrigation and other purposes is the ground water. According to El-Shazly (1976), Ezz El- Deen (1996) and the Egyptian Geological Survey (1999) reported that, the hydrogeology of the Nubian aquifer in El- Kharga Oases is a succession overlain by variegated shale bed (Cap rock) and underlain by the basement complex. The whole thickness of deep aquifer varies from about $230 \mathrm{~m}$ in the south to more than $750 \mathrm{~m}$ in the north. The depth of shallow aquifer in El- Kharga Oases varies from $35 \mathrm{~m}$ below ground surface at the south to $16 \mathrm{~m}$ at north, so the piezometric water level varies from 72 to $26 \mathrm{~m}$. from the south to the north. This indicates that, the general trend of ground water movement tend to be from the south to the north. However, the productive layers in the past were generally exploited under artesian flowing condition. At present, pumping is necessary where all wells have stopped flowing due to over pumping and the consequent formation of regional cones of depression.

Zhongxin et al., (2004) reported that, remote sensing (RS) is defined as the acquisition of information about an object without being in physical contact with it. Remote sensing techniques have been utilized in soil science for many years as a tool for soil surveyors that reduce the time and expense of sampling. Some soil properties can also be delimeated from Satellite images using the band combinations and computational indices depending on the particular reflectance of each soil category (Sharma et al., 2006). 


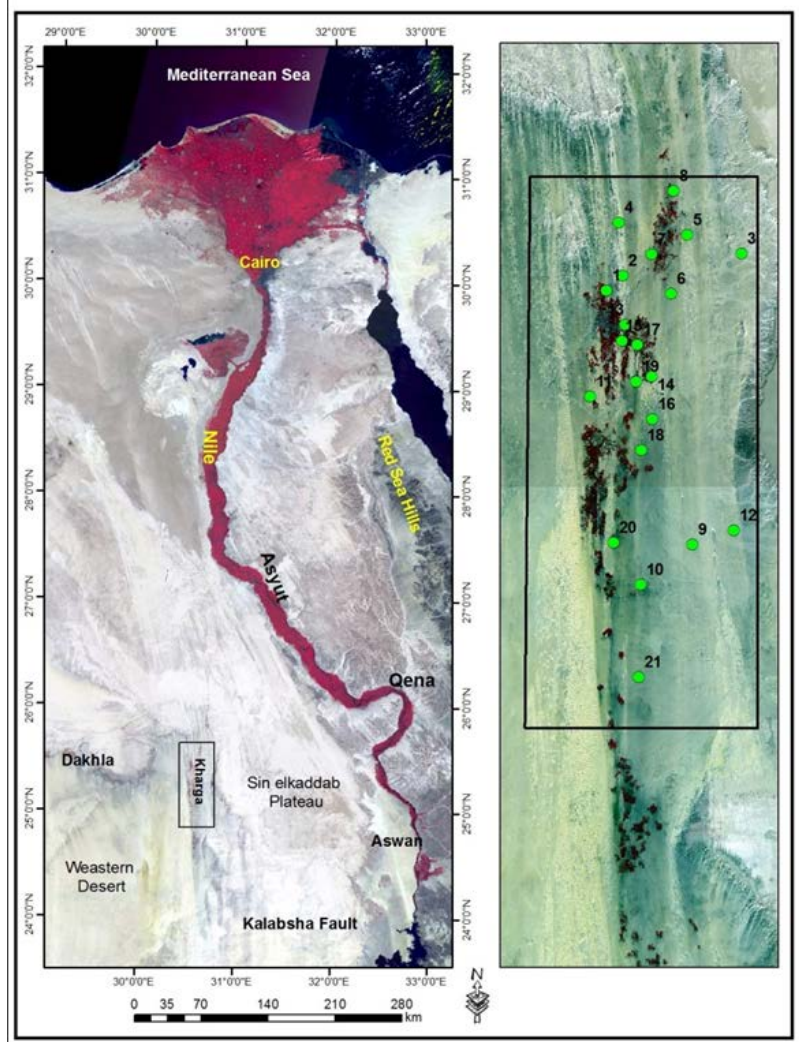

Fig. (1): Location of the study area.

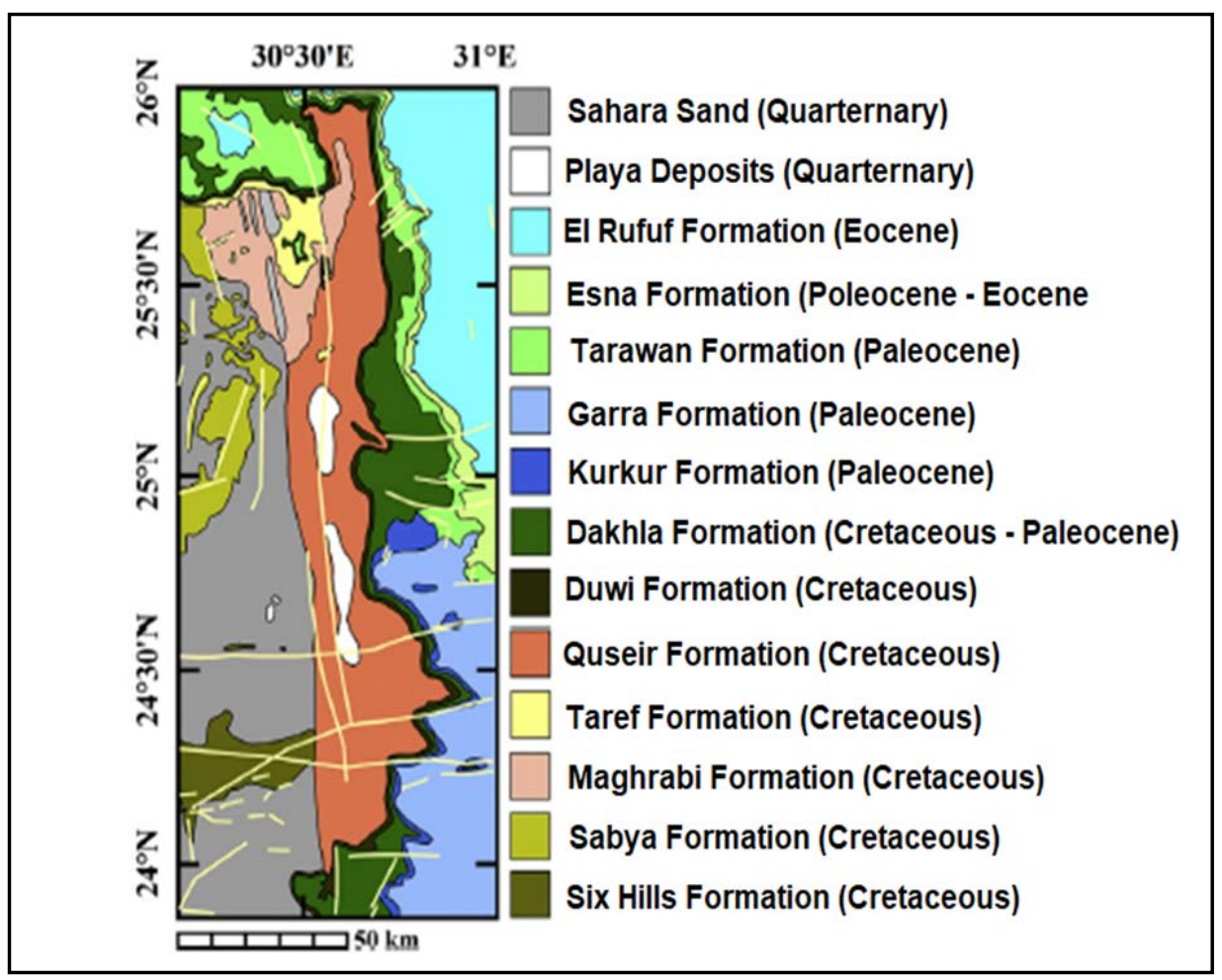

Fig. (2): Geological formation of El Kharga Oasis (after Hermina, 1990). 
On the other hand, geographic information system (GIS) is considered as an organized collection of computer hardware, software, spatial and nonspatial data that can help users for the efficient capture, storage update, manipulation analysis and management of all geographically referenced information. RS in combination with GIS techniques proved to be effective in sustainability and planning studies (Rajitha et al., 2006).

One of the ways to provide food is to increase production in area and to use the land with respect to its potentiality in an appropriate way. Land quality has been defined as "The condition and capacity of land", including its soil, climate, topography and biological properties for purpose of production, conservation and environmental management" (Pieri et al., 1995). Today advanced computer programs including two of data gathering systems, (GIS) and (RS) as well as assessment models contribute to the speed and efficiency of the overall planning process and allow access to large amounts of information quickly. Especially during the last decade, GIS and RS have received much attention in application related to resources at a large spatial scale (Green 1995) and (Hinton 1996).

The aims of this study is to identify the geomorphic units of El- Kharga oases area in the Western Desert using remote sensing and GIS techniques and evaluation the land and water resources for a sustainable agricultural development. The land suitability for a specific field, vegetable and fruit crops are also evaluated.

\section{MATERIALS AND METHODS}

Two Landsat 8 OLI satellite images with spatial resolutions of $30.6 \mathrm{~m}$. acquired in year 2015 for El- Kharga
Oases (Path 176 - row 42) and (path 176 row 43) were used for this research. The digital image processing was executed using ENVI 5.1 software (ITT, 2009). Image was stretched using linear $2 \%$, smoothly filtered and their histograms were matched according to Lillesand and Kiefer (1997).

Image was atmospherically corrected using FLASH module (ITT, 2009). The different landforms were initially determined and delineated from the satellite image. Digital Elevation Model (DEM) were produced from the shuttle radar topography mission (NCSA, 2005) and the available contour map (Figs 3 and 4) following the methodology developed by Dobas et al., (2002) and Kalogirow (2002). GIS works were performed to produce base, geomorphic units, soil taxonomy, capability and suitability maps of the studied area using Arc GIS 10.2 software (ESRI, 2014).

\section{Field work}

The preliminary geomorphic map was refined during the ground truth to the emphasis the boundaries between the geomorphic units. Twenty-one soil profiles (Fig. 5) were chosen representing the main geomorphic unit (Depression Floor) of the study area. Also, 120 mini pits were located to represent the different geomorphic units. Soil profiles were dug to $150 \mathrm{~cm}$. or to the lithic or water table level which is first contact. These profiles were described according to the Soil Science Division Staff (2017) and presented in Table (1). The profile sites and water samples are detected in the field by means of the Garmin 12 XL GPS Garmin Co. (1997). Sixty one soil samples and ten water samples were collected. The soil samples were air dried, crushed, sieved and used for physical and chemical analyses. 


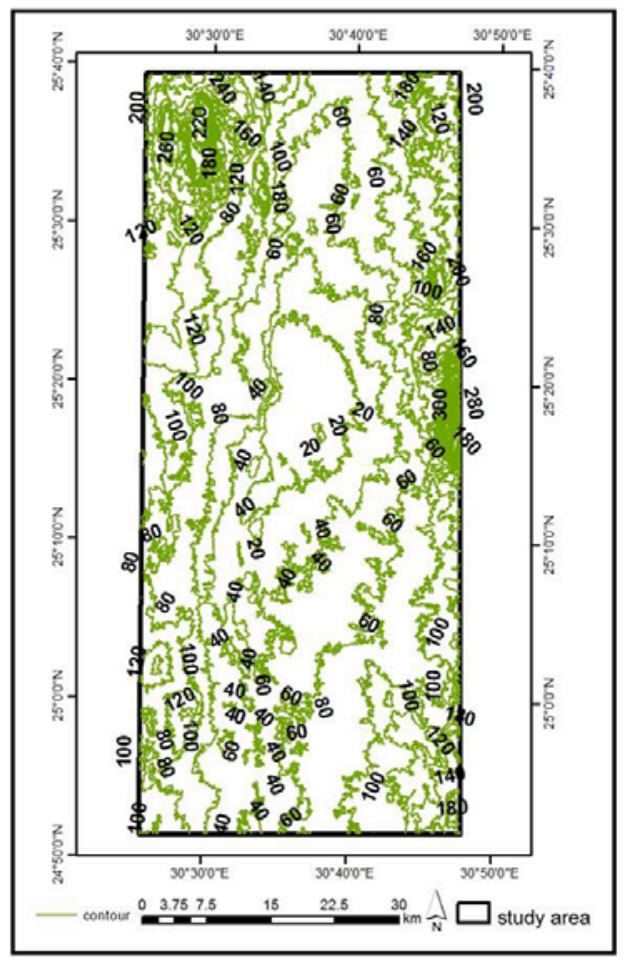

Fig. (3): Contour map of the study area.

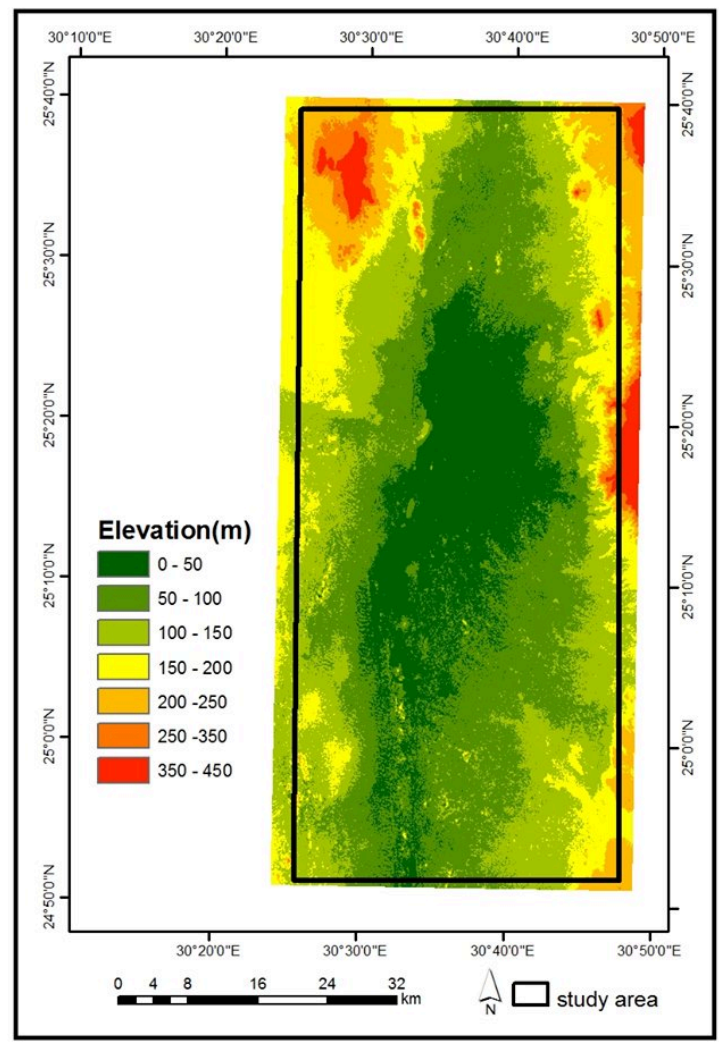

Fig. (4): Digital Elevation Model (DEM) of the studied area 


\begin{tabular}{|c|c|c|c|c|c|c|c|}
\hline $\begin{array}{c}\text { ***uo!peo!!!!ssejo } \\
\text { I!OS }\end{array}$ & $\begin{array}{l}\text { 峇 } \\
\text { مे }\end{array}$ & U & 帝 & $\begin{array}{l}\text { 山 } \\
0 \\
0 \\
0\end{array}$ & 吉 & 岂 & $\begin{array}{l}\text { 嶒 } \\
0 \\
0\end{array}$ \\
\hline $\begin{array}{l}\frac{2}{\frac{\pi}{0}} \\
\frac{0}{0} \\
\\
0 \\
0\end{array}$ & $\begin{array}{lll}n & n & 1 \\
ن & 0 & 1\end{array}$ & $\left|\begin{array}{lll}3 & 3 & 1 \\
0 & 0 & 1\end{array}\right|$ & $\begin{array}{lll}n & n & 1\end{array}$ & $\begin{array}{lll}n & n & 1 \\
ن & 0 & 1\end{array}$ & $\begin{array}{lll}3 & 3 & 1 \\
0 & 0 & 1\end{array}$ & $\begin{array}{lll}3 & 3 & 1 \\
0 & 0 & 1\end{array}$ & 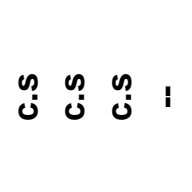 \\
\hline 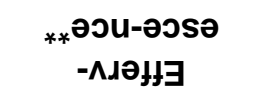 & 333 & $\begin{array}{lll}3 & 3 & 3\end{array}$ & 爮 & 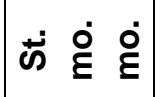 & 333 & $\stackrel{\dot{9}}{\xi} 3$ & 3333 \\
\hline $\begin{array}{l}0 \\
0 \\
\frac{c}{0} \\
\frac{0}{N} \\
\frac{.0}{0} \\
0 \\
0\end{array}$ & 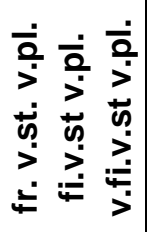 & 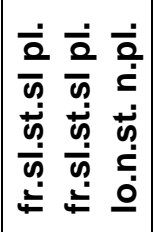 & 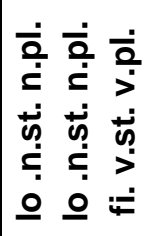 & 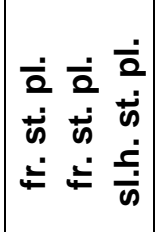 & 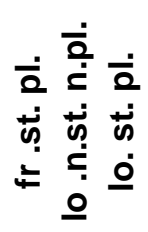 & 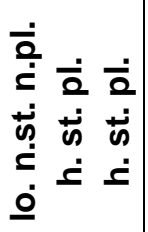 & 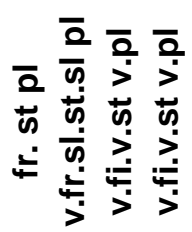 \\
\hline$\overline{\text { के }}$ & 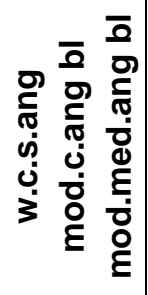 & 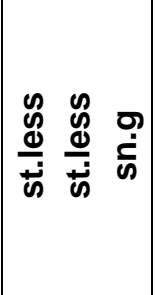 & | & 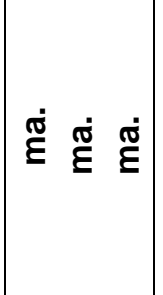 & 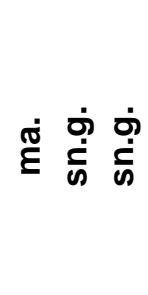 & ஸे & 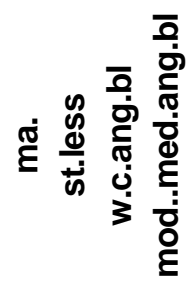 \\
\hline $\begin{array}{c}\% \\
\text { s|әлеגэ }\end{array}$ & ' 1 ' & 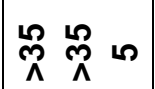 & | & 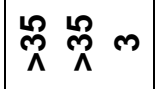 & $\stackrel{n}{ભ}$ & 뇩욱 N & . -100 \\
\hline 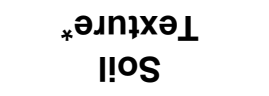 & $\cup \cup 0$ & $\vec{\omega}$ ๘ & u & 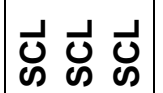 & $\vec{U} \backsim \infty$ & œ U. & U্口 ৩ ৩ \\
\hline \multirow{2}{*}{$\frac{\bar{n}}{\overline{0}}$} & $\stackrel{\sim}{\sim} \frac{m}{\gamma}$ & $\stackrel{\varrho}{\aleph} \frac{\mathfrak{m}}{6}$ & 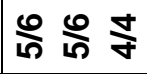 & $\stackrel{\varrho}{m} \frac{\nabla}{\nabla}$ & $\frac{m}{6} \frac{0}{6}$ & $\stackrel{\bullet}{*} \frac{0}{n}$ & $\stackrel{m}{g} \frac{m}{m} \stackrel{N}{\mathcal{N}}$ \\
\hline & 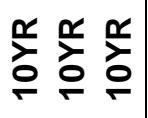 & 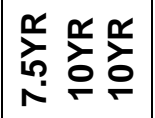 & 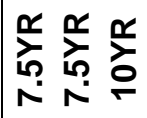 & 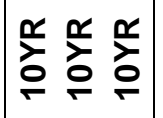 & 茓 & 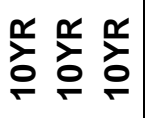 & 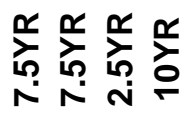 \\
\hline & $\frac{N}{6} \frac{m}{n}$ & $\frac{0}{0} \underset{ก}{\stackrel{m}{N}}$ & $\frac{0}{6} \frac{0}{6}$ & 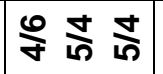 & $\stackrel{N}{N} \frac{m}{N}$ & $\stackrel{\bullet}{\bullet} \frac{0}{6}$ & $\frac{m}{n} \frac{m}{\frac{m}{n}} \frac{N}{n}$ \\
\hline & 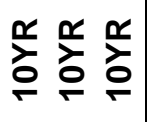 & 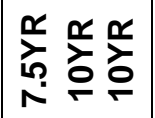 & 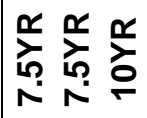 & 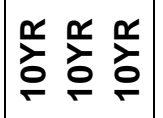 & 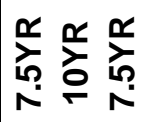 & 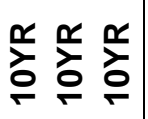 & 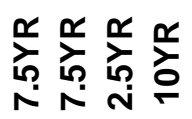 \\
\hline 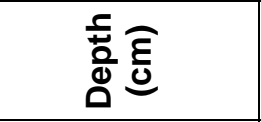 & 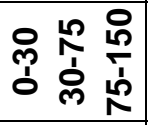 & 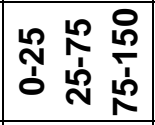 & 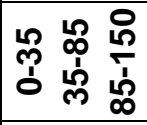 & 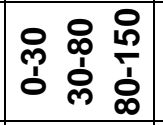 & 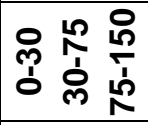 & 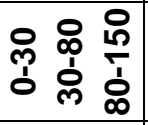 & 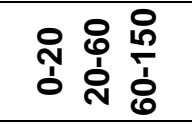 \\
\hline$\frac{0}{0} \frac{0}{2}$ & -1 & N & $\infty$ & ( & 욱 & 걱 & ה \\
\hline $\begin{array}{c}\text { St!un } \\
\text { ग!̣dıomoəo }\end{array}$ & \multicolumn{7}{|c|}{ u!e|d!pəd } \\
\hline
\end{tabular}




\begin{tabular}{|c|c|c|c|c|c|c|c|c|}
\hline \multicolumn{2}{|l|}{$\sum_{U}$} & \multicolumn{2}{|l|}{ 章 } & \multirow{2}{*}{ 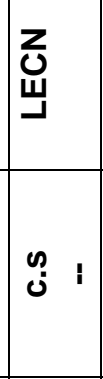 } & \multirow{2}{*}{ 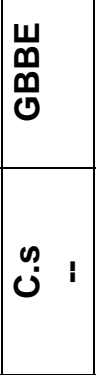 } & \multirow{2}{*}{ 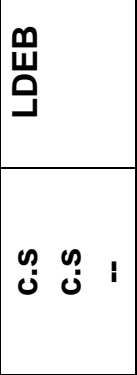 } & \multirow{2}{*}{ 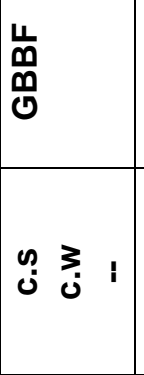 } & \multirow{2}{*}{ 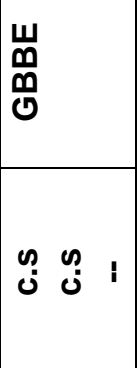 } \\
\hline i & $\begin{array}{ll}0 & 1 \\
0 & 1\end{array}$ & \begin{tabular}{ll|}
0 & 1 \\
0 & 1
\end{tabular} & $\mid \begin{array}{ll}n & : \\
0 & 1\end{array}$ & & & & & \\
\hline 3333 & $3 \stackrel{0}{\xi}$ & 33 & 33 & $\mid \begin{array}{ll}\dot{\rho} & \dot{0} \\
\dot{\varepsilon}\end{array}$ & $\dot{\omega} \dot{\omega}$ & 333 & $\stackrel{\dot{g}}{\xi} 33$ & $\dot{\omega} \stackrel{\dot{0}}{\xi}$ \\
\hline 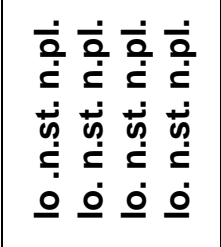 & 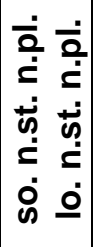 & 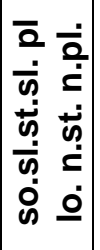 & 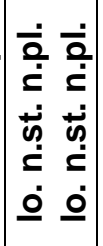 & 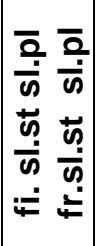 & 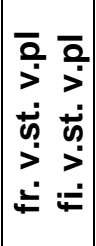 & 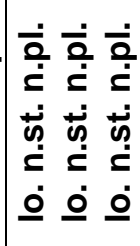 & 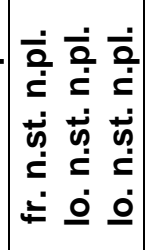 & 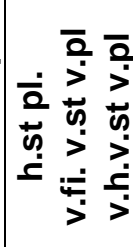 \\
\hline 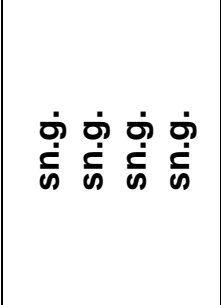 & 递 & 官 & $\left|\begin{array}{ll}\dot{0} & \vdots \\
\dot{\dot{v}} & \dot{\vdots} \\
\bar{c}\end{array}\right|$ & 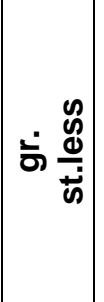 & $\begin{array}{l}\dot{\vdots} \\
\overline{0} \\
\dot{\sigma} \\
0 \\
0 \\
0 \\
\dot{0} \\
\dot{3}\end{array}$ & 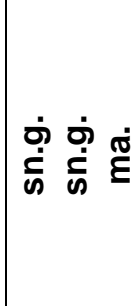 & 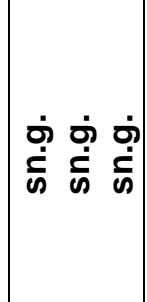 & 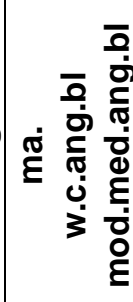 \\
\hline ـ & $r m$ & $\begin{array}{ll}n \\
n\end{array}$ & $\begin{array}{ll}-1 & -1\end{array}$ & 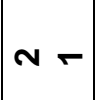 & ' ' ' & 온 의 욱 & L & ' ' \\
\hline $\operatorname{scs} \backsim$ & $\vec{\omega} \omega$ & の & a & ० ๘ & $\begin{array}{ll}ن & 0\end{array}$ & $\cos \theta$ & $u$ & $0 \cup 0$ \\
\hline 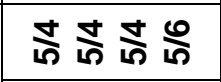 & $5 \frac{0}{6}$ & $\frac{6}{15} \frac{0}{51}$ & $\frac{7}{8} \frac{0}{8}$ & 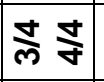 & $\frac{m}{\partial} \frac{m}{L}$ & $\frac{0}{6} \frac{0}{6} \frac{m}{5}$ & 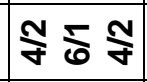 & $\frac{8}{8} \frac{0}{6}$ \\
\hline 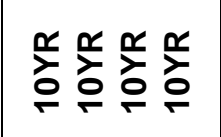 & 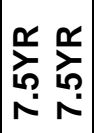 & 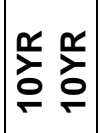 & 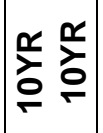 & 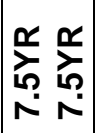 & 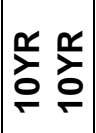 & 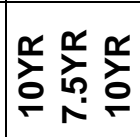 & 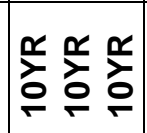 & 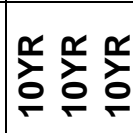 \\
\hline$\frac{5}{6} \frac{0}{6} \frac{m}{6} \frac{0}{6}$ & $\frac{0}{N} \frac{0}{N}$ & $\frac{0}{1}$ & $\frac{7}{5} \frac{0}{6}$ & $\frac{2}{4}$ & $\frac{\pi}{6}$ & $\frac{6}{N} \frac{9}{6}$ & $\frac{N}{N} \frac{N}{N}$ & $\frac{\pi}{2} \frac{1}{6}$ \\
\hline 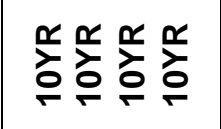 & 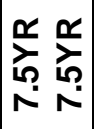 & 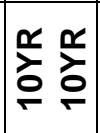 & 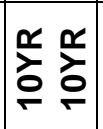 & 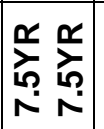 & 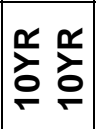 & 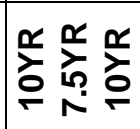 & 紊 & 兄 足 \\
\hline 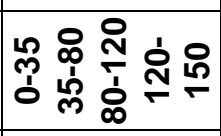 & 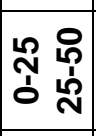 & 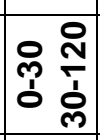 & 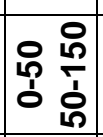 & 占 & 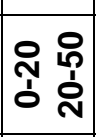 & 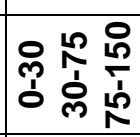 & 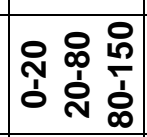 & 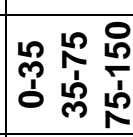 \\
\hline N & $\sigma$ & $\mathscr{G}$ & $\stackrel{\infty}{\rightarrow}$ & $m$ & ㄱ & n & 0 & 오 \\
\hline \multicolumn{4}{|c|}{ suna pues } & \multicolumn{2}{|c|}{$\begin{array}{l}\text { st!sodəp } \\
\text { !рем }\end{array}$} & \multicolumn{3}{|c|}{ exeld } \\
\hline
\end{tabular}




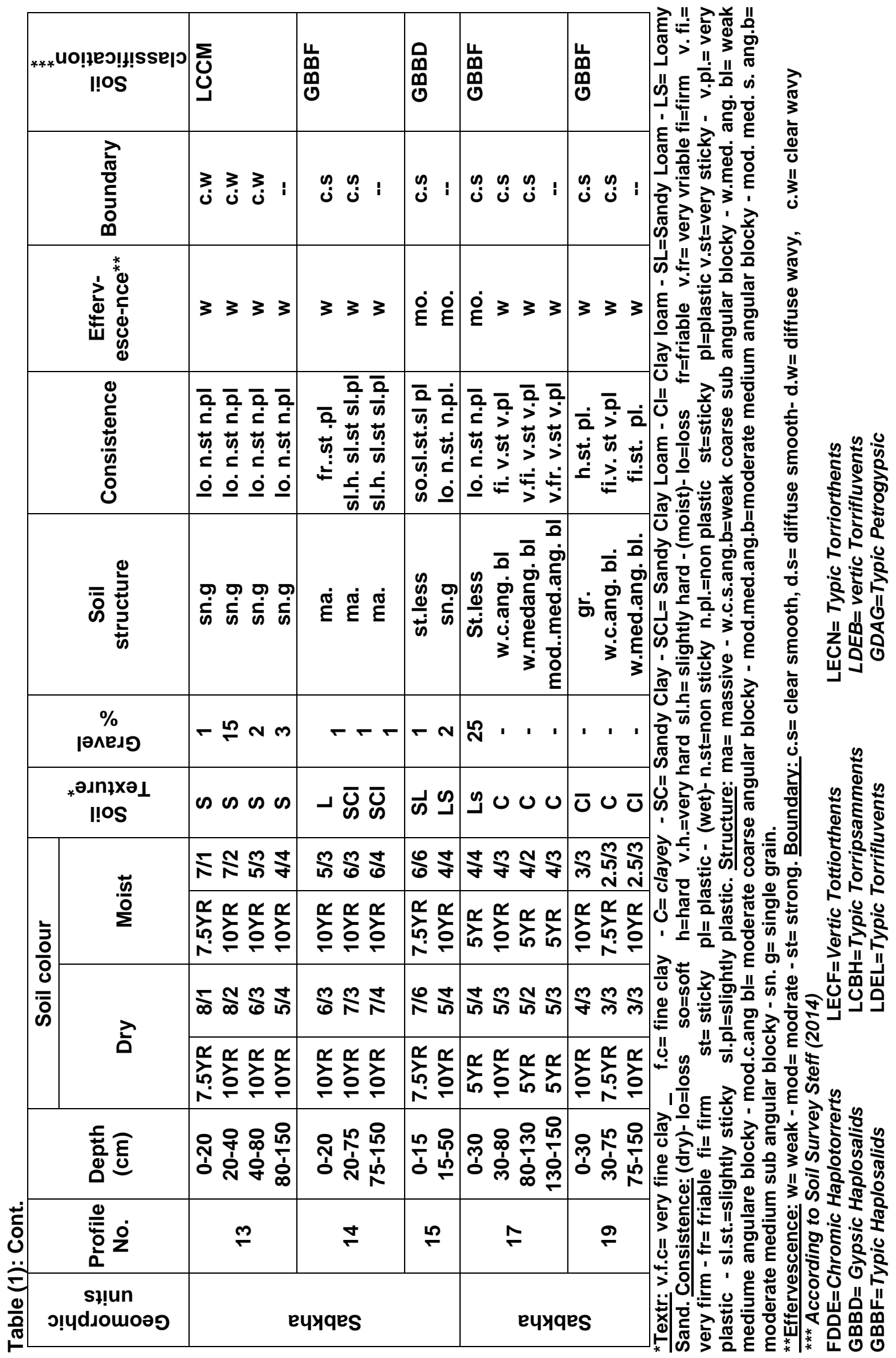




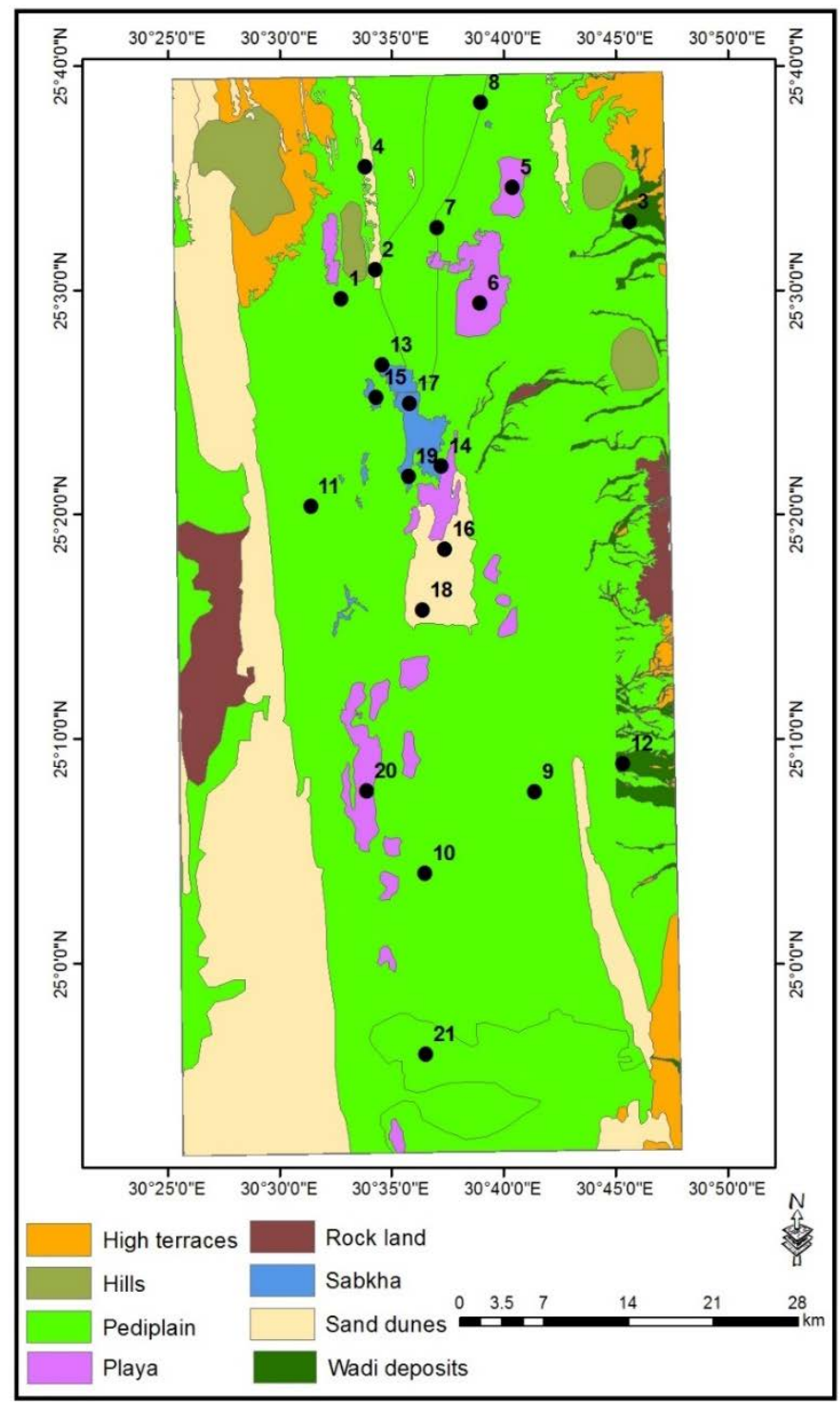

Fig. (5): Geomorphic map and Location of soil profiles

\section{Laboratory analysis}

Soil physical analysis

-Soil color in both wet and dry conditions was determined using Munsell Soil Color Charts (2010).

-Particle size distribution was determined according to Klute (1986) using hexametaphosphate as a dispersing agent.

\section{Soil chemical analysis}

The following analyses were carried out according to the methods outlined in Burt (2004): calcium carbonate, gypsum, organic matter, Electrical conductivity $(E C e)$, Soil reaction $(\mathrm{pH})$ in the soil paste, cation exchange capacity (CEC), and exchangeable sodium percentage (ESP).

Ten irrigation water samples were collected from some wells and filtered with Whatman paper filter. Water reaction $(\mathrm{pH}), \mathrm{ECe}$, total dissolved solids (TDS), soluble cations and anions, Sodium adsorption ratio ( SAR), Residual sodium carbonate (RSC) and some trace elements ( $\mathrm{B}, \mathrm{Fe}, \mathrm{Mn}, \mathrm{Zn}$ and $\mathrm{Cu}$ ) were determined for these water samples using the methods described in Burt (2004). Suitability of 
water for irrigation was determined according to limitation outlined by FAO (1985).

The investigated soils were classified up to sub great group level based on the available climatic data, soil morphology, physical and chemical properties according to Soil Survey Staff (2014).

Soil limitations as well as land capability evaluation was obtained by using the parametric systems based on the basis of Sys and Verheye (1978) and Sys et al., (1991). Also, evaluation of land suitability for growing specific field, vegetables, and fruit crops was done according to Sys et al., (1991) and Sys et al., (1993) by matching the land characteristics with crop requirements.

\section{RESULTS AND DISCUSSION}

\section{Geomorphology of El-Kharga Oases}

The geomorphic units distinguished in the studied area as a result of the satellite images interpretation and field observations are shown in Fig. (3) and Table (2). They can be broadly grouped in the following three major geomorphic units.

1. High Land including four sub units landforms namely; rocky land; foot hills, low slope and mountain.

2. Plateau including; gravelly plain, low cover with sand sheet plain, almost flat plain and undulating plain.

3. Depression Floor having nine sub unit landforms: Pediplain, Wadi Deposits, Playa, Sabkha, Decantation Basin, Agriculture areas, Sand Sheets, Sand Dunes and Nabkes Dunes.

The Depression Floor landform unit shows the most suitable unit for developmental agricultural plans. The morphological, physical and chemical characteristics for the soil profiles representing the soils of the sub unites of this landform are presented Tables ( 1 and 3 ) and could be summarized as follows.

\section{1- Soils of Pedi plain (DF111)}

This sub unit occupies the most of ElKharga Oases area and extends from north to southward as well. It is forming a narrow belt between the "rock exposure " unit in the east and undulating sand dunes in the west, covering approximate area of $862.8 \mathrm{~km} 2$ (207072 feddans). The surfaces are almost flat and locally covered by desert pavement. These soils are very deep. Their representative profiles are 1, 7,8,9,10,11 and 21. Soil dry colour varies between weak red (2.5 YR $5 / 2$ ) and very pale brown (10 YR 7/3). While the moist colour ranges from weak red (2.5 yr4/2) to pale brown (10 YR 6/3). Soil texture varies from sand to clay with gravel content ranges from $1 \%$ to $>30 \%$ by volume. Soil consistence coincides well with soil texture and ranged from nonsticky, to very sticky and non-plastic to very plastic.

Data in Table (3) reveal that, the soil reaction ranged from neutral to strongly alkaline as revealed by $\mathrm{pH}$ values that ranged from 6.71 to 8.83 . The soil salinity values indicate that these soils are non to very extremely saline as indicating from ECe values that varied from 1.42 to 123.1 $\mathrm{dsm}^{-1}$. Organic matter content is generally very low, ranges from 0.02 to $0.87 \%$ owing to the prevalence of arid condition, which facilitate the decomposition of the organic matter. $\mathrm{CaCO}_{3}$ content varied from 0.04 to $18.06 \%$ with an irregular distribution pattern with soil profile depths. Gypsum content ranged from 0.01 to $2.68 \%$. The cation exchange capacity (CEC) ranged

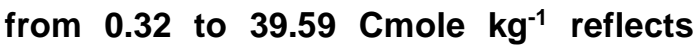
differences in clay and silt content among the soil profile and their layers. Exchangeable sodium percentage (ESP) values varied from $0.24 \%$ to $91.16 \%$. 


\begin{tabular}{|c|c|c|c|c|c|c|c|c|}
\hline$\overbrace{}^{\circ}$ & 苛 & $\begin{array}{l}\infty \\
0 \\
0\end{array}$ & 용 $\stackrel{9}{\stackrel{9}{N}}$ & L & 엄 엇 궁 웅 & $\stackrel{\vec{m}}{\vec{m}}$ & 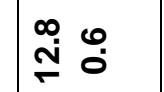 & ठ̊ำ \\
\hline 矢 & 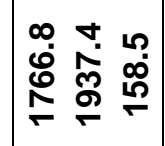 & $\begin{array}{c}m \\
\dot{o} \\
\stackrel{\sim}{\sim} \\
\end{array}$ & 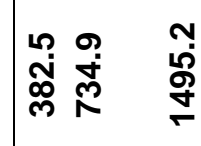 & 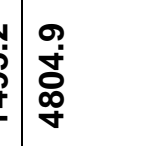 & 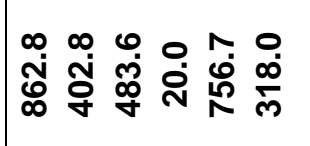 & 旋 & 芦 & 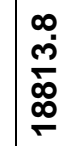 \\
\hline 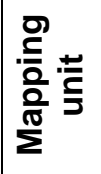 & 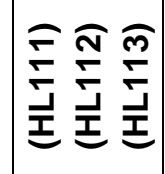 & . & 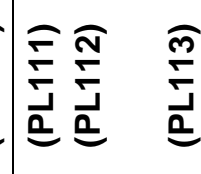 & 赵 & 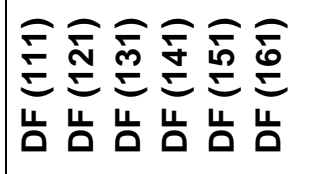 & $\begin{array}{l}\mathcal{A} \\
\text { dู } \\
\text { ü }\end{array}$ & 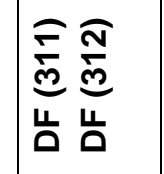 & 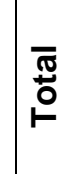 \\
\hline 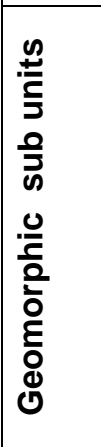 & 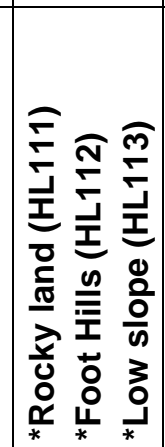 & 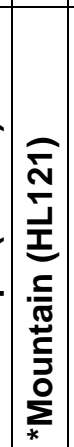 & 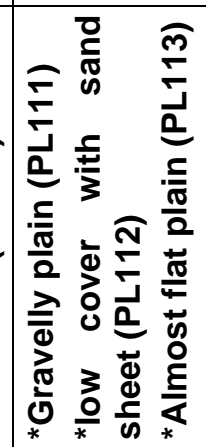 & 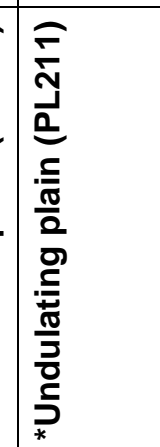 & 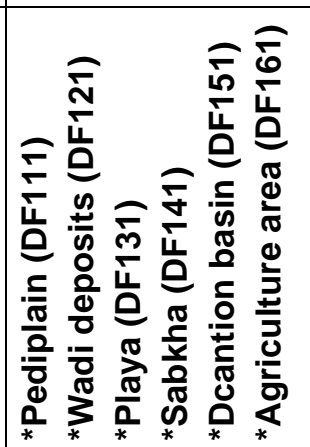 & 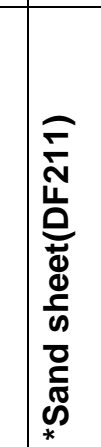 & 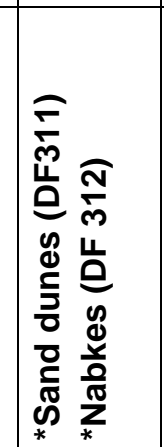 & \\
\hline 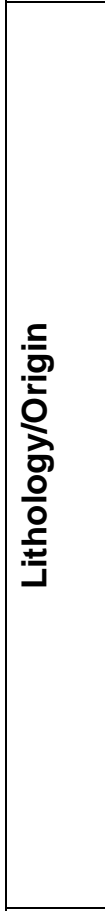 & 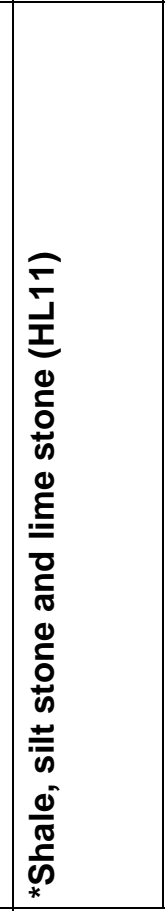 & 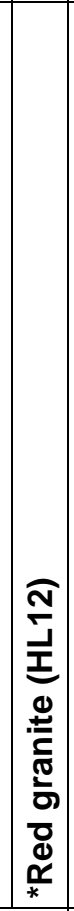 & 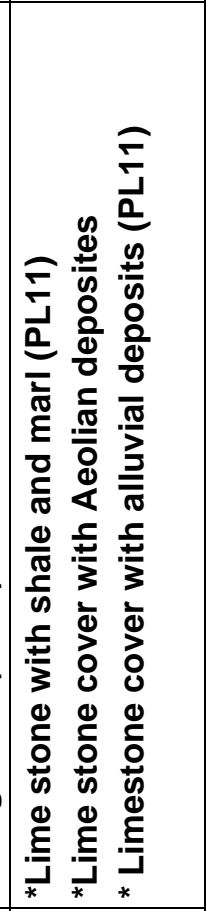 & 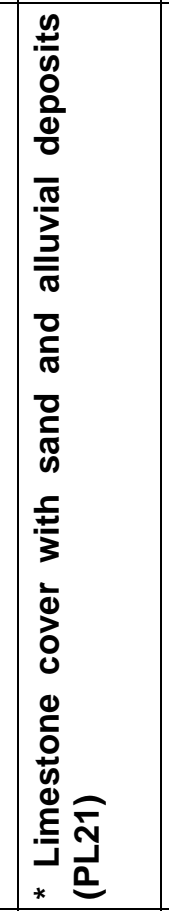 & 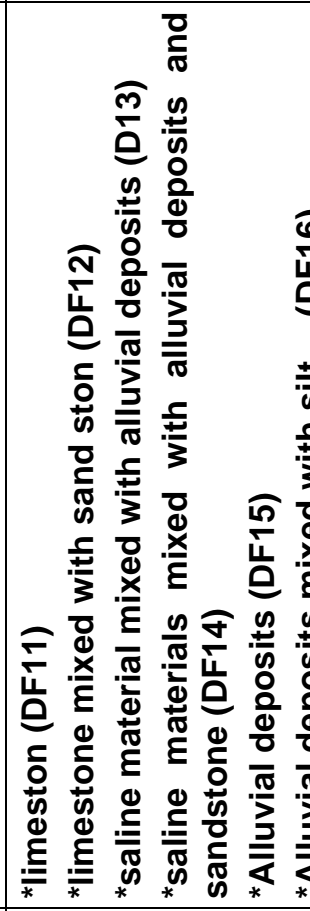 & 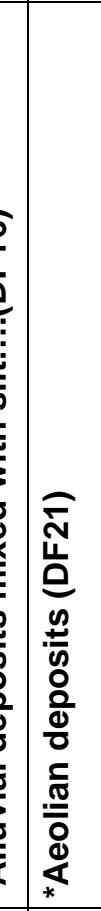 & 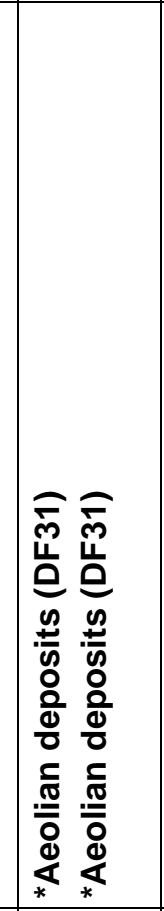 & \\
\hline 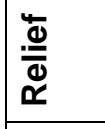 & 츨 & & $\begin{array}{l}\frac{\pi}{\pi} \\
\frac{\pi}{4} \\
\dot{\alpha} a\end{array}$ & 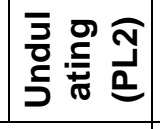 & 奠紊 & 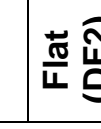 & 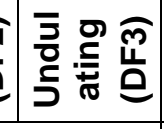 & \\
\hline 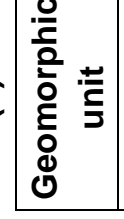 & 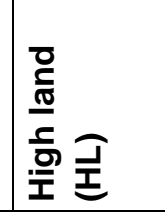 & & 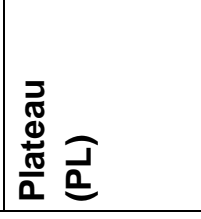 & & 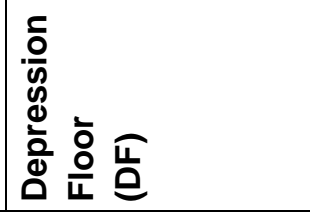 & & & \\
\hline
\end{tabular}




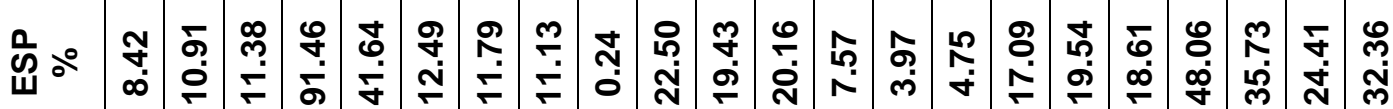

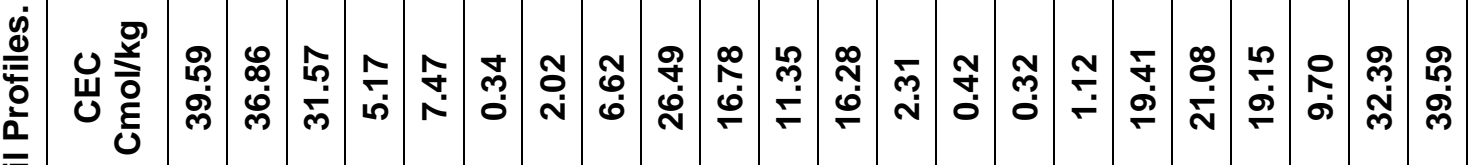

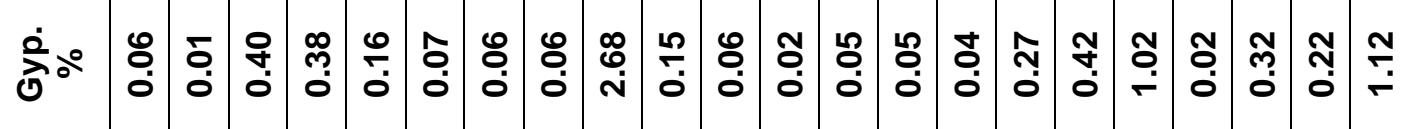

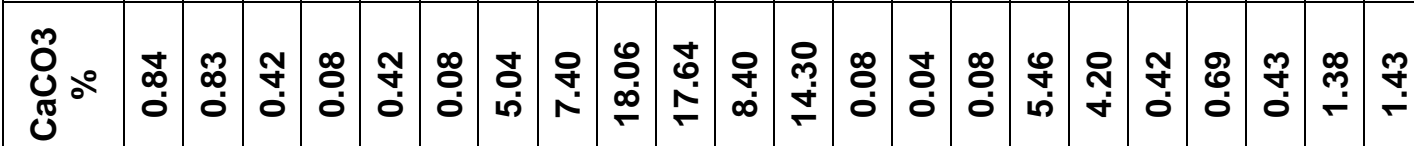

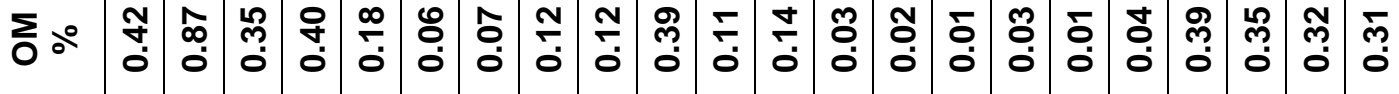

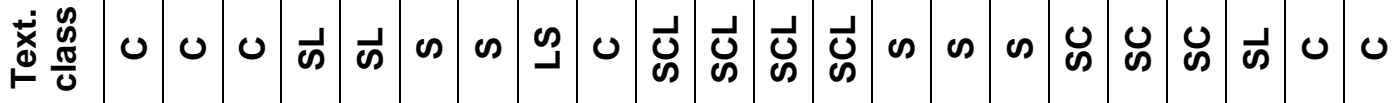

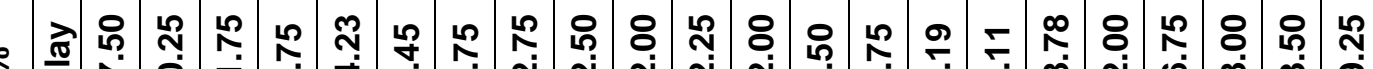

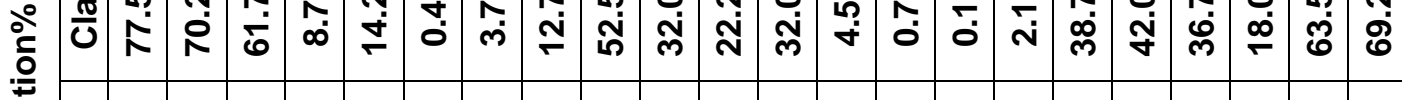
章

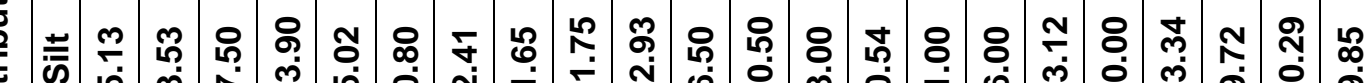
๒ $\stackrel{N}{n}$ の ๗)

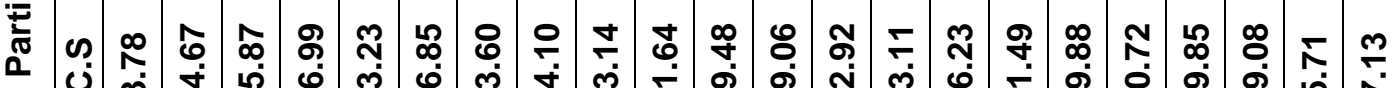

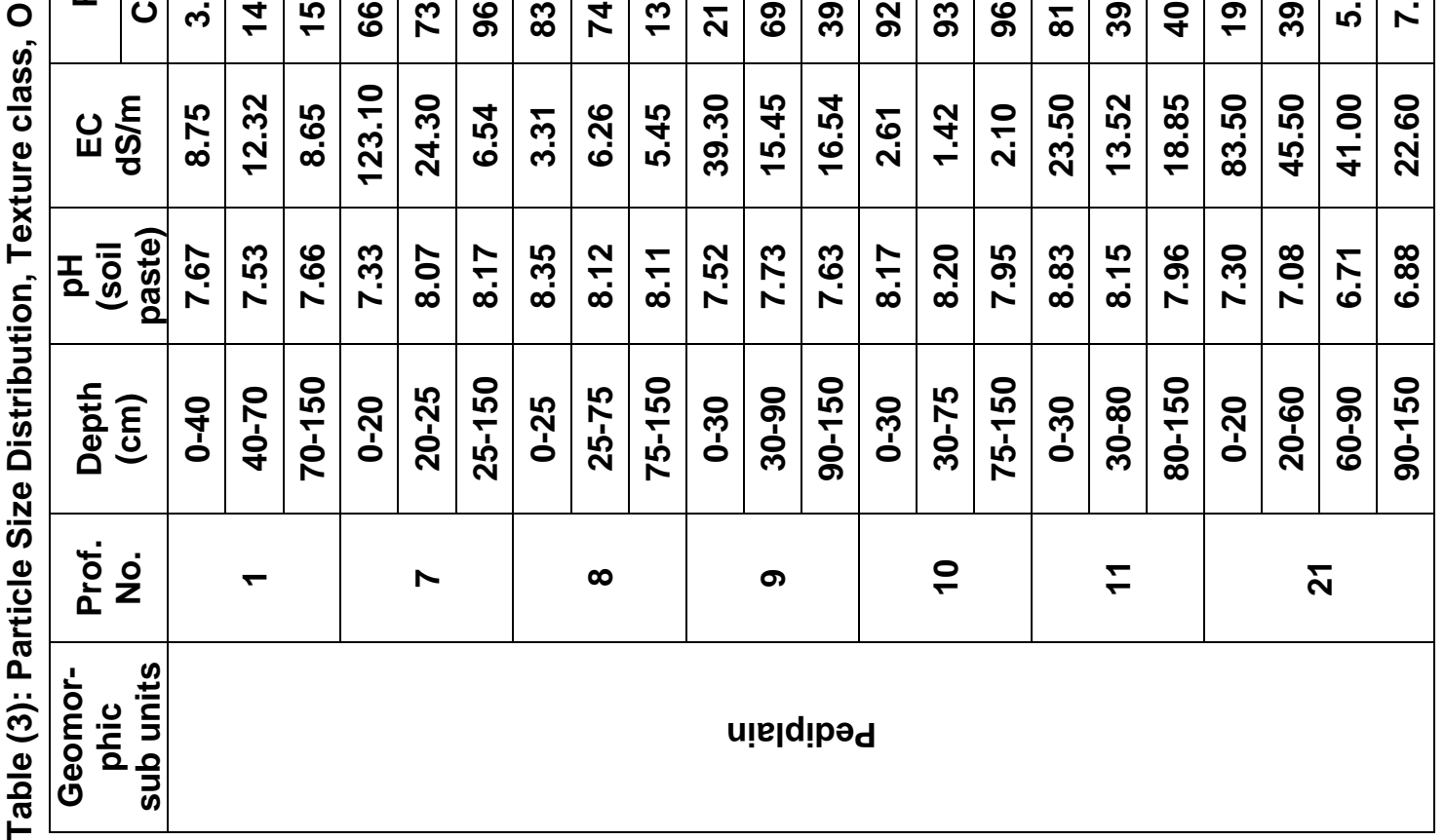




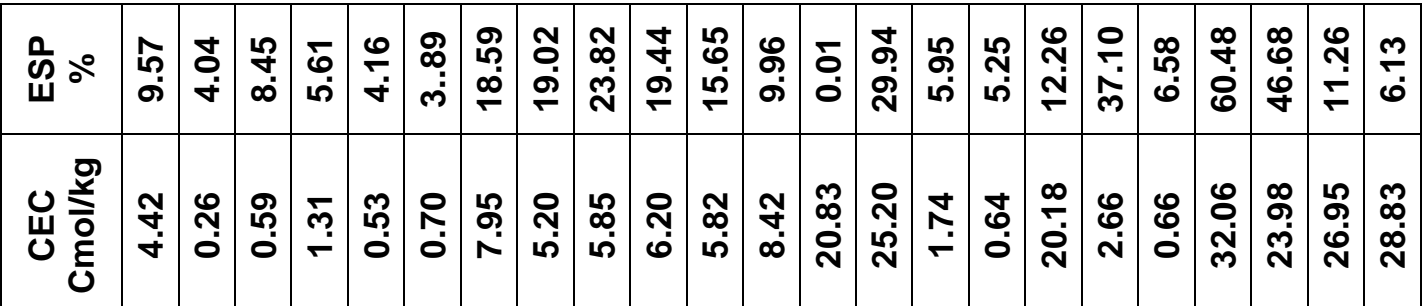

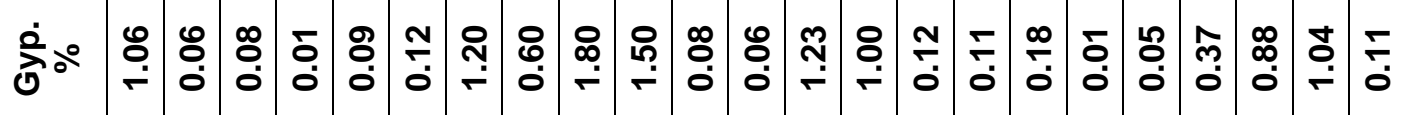

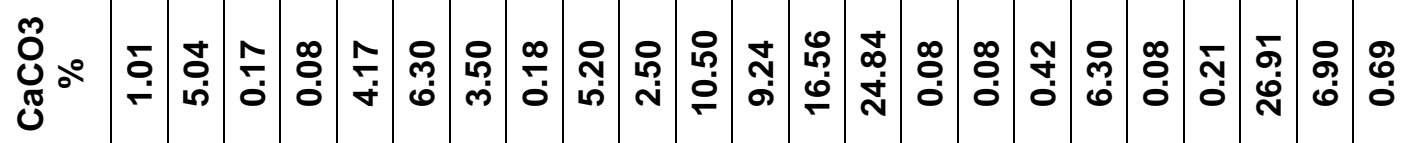

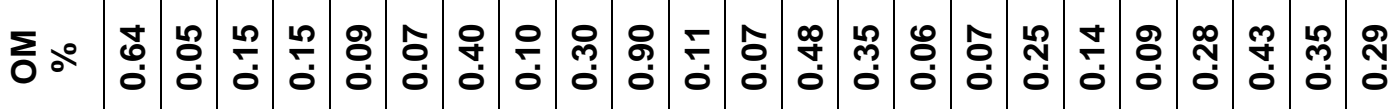

䒝兽

สิ సุ ఏ气

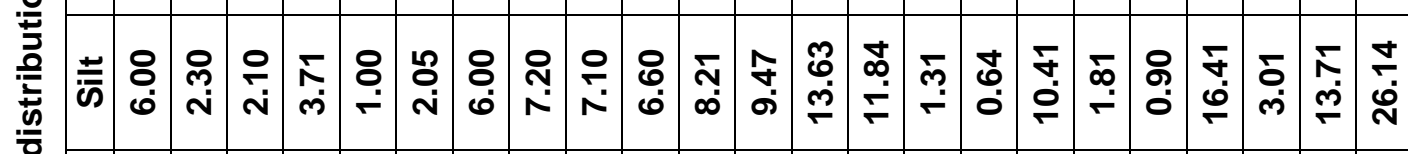

芯 $\backsim$ ⿹

凹

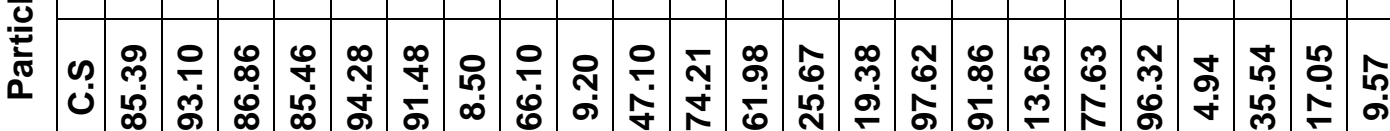

U

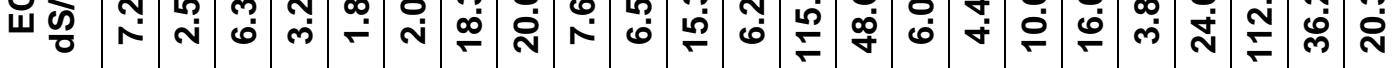

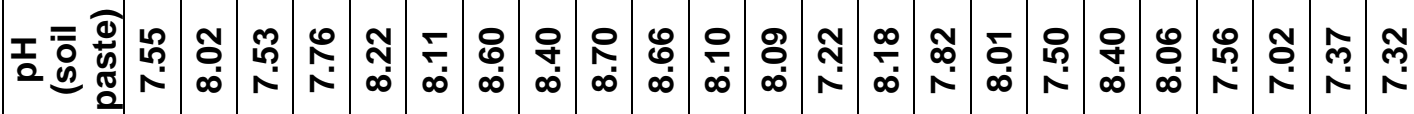

들

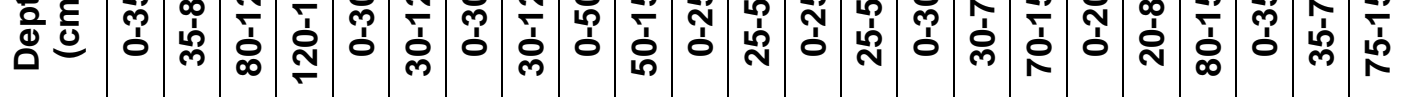

\begin{tabular}{|c|c|c|c|c|c|c|c|c|c|}
\hline पัँ & $N$ & $\theta$ & $\stackrel{0}{-1}$ & $\stackrel{\infty}{\rightarrow}$ & $m$ & สี & م & 0 & ㅇ \\
\hline 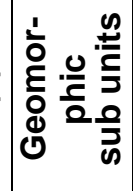 & \multicolumn{4}{|c|}{ suna pues } & \multicolumn{2}{|c|}{$\begin{array}{l}\text { st!sodəp } \\
\text { !peM }\end{array}$} & & \multicolumn{2}{|c|}{ exeld } \\
\hline
\end{tabular}




\begin{tabular}{|c|c|c|c|c|c|c|c|c|c|c|c|c|c|c|c|c|c|c|}
\hline \multicolumn{2}{|c|}{ 鿖。 } & $\begin{array}{l}-1 \\
0 \\
0\end{array}$ & ङั & $\stackrel{\text { no }}{\text { g }}$ & $\begin{array}{l}\stackrel{+}{\infty} \\
\stackrel{J}{+}\end{array}$ & \begin{tabular}{c}
\multirow{g}{*}{} \\
$\dot{G}$
\end{tabular} & $\begin{array}{l}\stackrel{n}{\Lambda} \\
\text { N่ }\end{array}$ & ભ̊ & 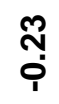 & $\begin{array}{c}\stackrel{m}{m} \\
\stackrel{y}{y}\end{array}$ & $\begin{array}{l}\mathscr{Q} \\
\stackrel{0}{0}\end{array}$ & 足 & $\begin{array}{l}0 \\
\tilde{m} \\
\dot{\omega}\end{array}$ & $\begin{array}{l}\text { : } \\
\text { N }\end{array}$ & $\begin{array}{l}0 \\
\stackrel{0}{0} \\
0\end{array}$ & ్ֶల్ & $\begin{array}{l}\text { R } \\
8 \\
8\end{array}$ & \\
\hline \multicolumn{2}{|c|}{ U } & స్ & $\stackrel{m}{m}$ & ָָ & స్ల & ה্ & 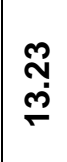 & $\begin{array}{l}0 \\
0 \\
0 \\
0\end{array}$ & $\underset{\infty}{N}$ & 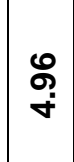 & 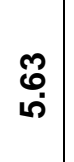 & 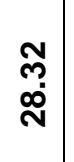 & 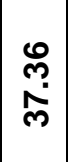 & $\begin{array}{l}0 \\
\stackrel{9}{1} \\
0 \\
0\end{array}$ & 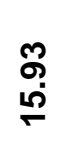 & $\begin{array}{l}\stackrel{\Xi}{0} \\
\stackrel{0}{0}\end{array}$ & $\begin{array}{l}\text { ధ̊ } \\
\infty \\
\text { ஸे }\end{array}$ & \\
\hline \multicolumn{2}{|c|}{$\sum_{0}^{i} \partial^{\circ}$} & 움 & $\stackrel{0}{\stackrel{1}{0}}$ & 궁 & $\begin{array}{l}0 \\
\stackrel{-1}{0}\end{array}$ & ڤ̊̆ & 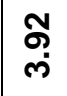 & ơ & $\underset{7}{-1}$ & $\begin{array}{l}N \\
\mathfrak{N}\end{array}$ & $\stackrel{-}{ה}$ & ก̊ & - & $\begin{array}{l}0 \\
\stackrel{1}{0}\end{array}$ & $\underset{\infty}{\mathscr{Y}}$ & సి & 굼 & di \\
\hline \multicolumn{2}{|c|}{ ర్ల్ర } & ભ̊ & $\stackrel{\text { m̊ }}{0}$ & : & $\stackrel{\infty}{\circ}$ & ન્ & ?̊ & ֻั? & สี & సี & 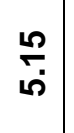 & $\stackrel{\mathfrak{N}}{\mathfrak{i}}$ & $\begin{array}{l}0 \\
0 \\
0\end{array}$ & 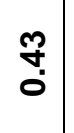 & ঙ্ণ & స̃ & ন্ণ & $\begin{array}{l}\frac{\pi}{0} \\
0 \\
\text { IJ }\end{array}$ \\
\hline \multicolumn{2}{|c|}{$\sum_{0} 0$} & 웅 & : & \%̊. & : & 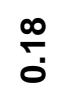 & $\stackrel{m}{9}$ & o̊ & ơ & $\stackrel{\infty}{+}$ & $\stackrel{9}{\stackrel{9}{0}}$ & $\begin{array}{l}8 \\
0 \\
0\end{array}$ & 文 & $\begin{array}{l}\text { ల్ } \\
0\end{array}$ & 국 & స̂. & ஜ: & \\
\hline \multicolumn{2}{|c|}{ 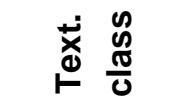 } & $\omega$ & $\infty$ & $\omega$ & $\omega$ & 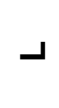 & $\vec{U}$ & $\vec{U}$ & $\vec{\omega}$ & s & n & $\underset{\leftarrow}{U}$ & $\mid$\begin{tabular}{c}
0 \\
\hdashline \\
\hdashline
\end{tabular} & 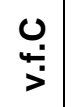 & $\vec{U}$ & 0 & $\vec{u}$ & \\
\hline \multirow{4}{*}{ 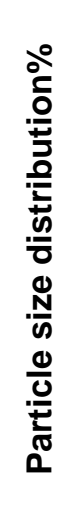 } & $\frac{\vec{\pi}}{0}$ & ָ̃ & @̊ & ơ & Nָ & م & $\begin{array}{l}\stackrel{10}{N} \\
\stackrel{N}{N}\end{array}$ & స̃ & $\begin{array}{l}-1 \\
\dot{6} \\
\stackrel{-}{1}\end{array}$ & $\begin{array}{l}8 \\
\infty\end{array}$ & 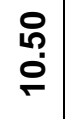 & $\begin{array}{l}\stackrel{L}{N} \\
\dot{\leftarrow}\end{array}$ & $\begin{array}{l}8 \\
\dot{T} \\
\end{array}$ & $\underset{i}{i}$ & $\stackrel{N}{N}$ & 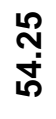 & $\begin{array}{l}\stackrel{n}{N} \\
\dot{m}\end{array}$ & \\
\hline & 竎 & 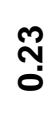 & تِ & $\stackrel{\substack{p \\
0}}{0}$ & تِ & $\begin{array}{l}\text { R } \\
\text { ㄱ }\end{array}$ & స્さ & $\begin{array}{l}\text { త్ } \\
\stackrel{\leftrightarrow}{0}\end{array}$ & $\begin{array}{l}\infty \\
\stackrel{\circ}{0} \\
\sigma\end{array}$ & $\begin{array}{l}\text { N̦ } \\
\text { - }\end{array}$ & 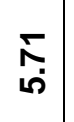 & $\begin{array}{l}\infty \\
\infty \\
\stackrel{N}{N}\end{array}$ & $\begin{array}{c}\text { g } \\
\dot{0} \\
\stackrel{9}{9}\end{array}$ & 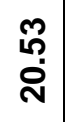 & $\begin{array}{l}\text { ల్ } \\
\text { N }\end{array}$ & $\begin{array}{l}\stackrel{0}{2} \\
\text { N }\end{array}$ & 今े & \\
\hline & $\begin{array}{l}\sim \\
4\end{array}$ & تָ & ְִ & $\stackrel{\text { m }}{\text { r }}$ & $\stackrel{m}{\circ}$ & ס̊ & $\begin{array}{l}\infty \\
\stackrel{1}{m} \\
-1\end{array}$ & $\begin{array}{l}m \\
\dot{y}\end{array}$ & مُ & 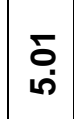 & 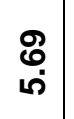 & $\underset{\text { İ }}{\stackrel{-}{ت}}$ & 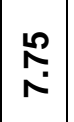 & $\underset{\substack{\text { } \\
\infty}}{ }$ & 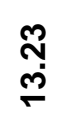 & $\begin{array}{l}\stackrel{9}{+} \\
\infty \\
\stackrel{+}{+}\end{array}$ & $\begin{array}{l}\stackrel{0}{0} \\
\infty\end{array}$ & \\
\hline & u & 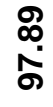 & $\begin{array}{l}8 \\
\vdots \\
\vdots\end{array}$ & 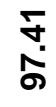 & $\begin{array}{l}8 \\
\text { ஜ̊ }\end{array}$ & గ్ & $\begin{array}{l}\text { ֶָ. } \\
\text { N̦ }\end{array}$ & 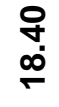 & ल्ల్ & $\begin{array}{l}\hat{N} \\
\dot{0}\end{array}$ & $\begin{array}{l}0 \\
\stackrel{9}{a} \\
\infty \\
\end{array}$ & $\begin{array}{l}0 \\
\dot{m}\end{array}$ & $\begin{array}{l}0 \\
\mathfrak{N} \\
\mathbf{N}\end{array}$ & N̦ & $\underset{\stackrel{+}{N}}{\stackrel{\text { N }}{n}}$ & น̊ & సี่ & \\
\hline \multicolumn{2}{|c|}{ U } & $\begin{array}{l}\text { U్ } \\
\text { N }\end{array}$ & ڤ્ડ & 守 & $\begin{array}{l}\text { Oे } \\
\text { ป }\end{array}$ & 오ํ & ণิ & 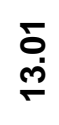 & $\begin{array}{l}\text { \& } \\
\text { Нู่ }\end{array}$ & $\begin{array}{l}0 \\
\infty \\
0 \\
0\end{array}$ & $\begin{array}{l}\text { P } \\
\infty \\
\text { m }\end{array}$ & 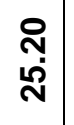 & $\begin{array}{c}\stackrel{\leftrightarrow}{0} \\
\dot{m}\end{array}$ & $\begin{array}{c}\text { กิ } \\
\text { ஸे }\end{array}$ & $\begin{array}{l}8 \\
\dot{0} \\
\infty\end{array}$ & $\begin{array}{l}\text { 우 } \\
\text { 유 } \\
\infty\end{array}$ & $\begin{array}{l}\text { N } \\
\text { ¿ั }\end{array}$ & \\
\hline \multicolumn{2}{|c|}{ 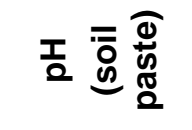 } & $\underset{\infty}{\stackrel{9}{9}}$ & $\underset{⿱ 乛}{\stackrel{f}{N}}$ & $\begin{array}{l}\infty \\
\stackrel{\infty}{\infty} \\
0\end{array}$ & مั & 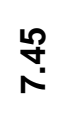 & 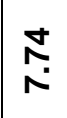 & นั & $\begin{array}{l}\stackrel{L}{L} \\
6 \\
6\end{array}$ & 오 & ָ̊. & 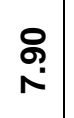 & ְ̊ㅜ & 市 & $\stackrel{\substack{m \\
0}}{0}$ & $\stackrel{0}{0}$ & '-1 & \\
\hline \multicolumn{2}{|c|}{ 吾 } & స్ ָ̊ & $\begin{array}{l}\text { டิ } \\
\text { N่ं }\end{array}$ & $\begin{array}{l}8 \\
\vdots \\
\text { ì }\end{array}$ & 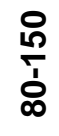 & ণ্ণ & $\begin{array}{l}\text { ¿ } \\
\text { ஸें }\end{array}$ & 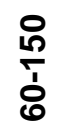 & $\stackrel{\text { n? }}{\grave{b}}$ & 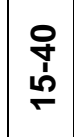 & ర్లి & $\begin{array}{l}0 \\
0 \\
0 \\
0 \\
\text { j }\end{array}$ & $\begin{array}{c}0 \\
\stackrel{m}{7} \\
\grave{1} \\
\infty\end{array}$ & 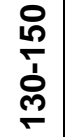 & ర్లి & $\begin{array}{l}\stackrel{n}{R} \\
\text { oे }\end{array}$ & $\begin{array}{l}\stackrel{0}{7} \\
\text { 官 }\end{array}$ & \\
\hline \multicolumn{2}{|c|}{ 흠 } & \multicolumn{4}{|c|}{$\stackrel{m}{\rightarrow}$} & \multicolumn{3}{|c|}{$\underset{ت}{ }$} & \multicolumn{2}{|c|}{ ?口 } & \multicolumn{4}{|c|}{ ন } & \multicolumn{3}{|c|}{$\stackrel{9}{\rightarrow}$} & \\
\hline \multicolumn{2}{|c|}{ 衣 } & \multicolumn{9}{|c|}{ sł!sodəp !peM } & \multicolumn{7}{|c|}{ ечY्रqеs } & \\
\hline
\end{tabular}




\section{2- Soils of sand dunes (DF311)}

This sub unit occupies a rather less extended small patches within the northern and middle parts of El-Kharga Oases. Also, it dominates in the western sides of El-Kharga Oases and extends from south to north, covering approximate area of $2414.7 \mathrm{~km}^{2}$ (579528 feddans) and representing by profiles 2 , 4,16 and 18. Its surfaces are undulating which are mostly covered by aeolian deposits of the Great Sand Sea. The majority of this sub unit have a moderately deep to very deep sandy soils with very few fine gravels content ranging from 1 to $7 \%$ by volume. Soil dry and moist colour varies from reddish yellow (7.5 YR 7/6) to brownish yellow (10 YR 6/6/). Soil texture class is sand or loamy sand throughout the entire profile depths, except for the surface layers of profiles 4 and 6 where the texture class is sandy loam with single grain structure throughout the entire profile depths. Soil consistence varied from non-sticky to slightly sticky and non-plastic to slightly plastic, (Table, 1).

The analytical data in Table (3) reveal that, soil reaction is slightly alkaline to strongly alkaline with $\mathrm{pH}$ values ranged between 7.73 to 8.7 . The soils of this geomorphic unit are non to strongly saline where ECe values ranged from 1.22 to $20.0 \mathrm{dSm}-\mathbf{1}$. Organic matter content is very low not exceeds $0.9 \%$. The soils are non-calcareous to slightly calcareous having a total carbonate content range from 0.08 to $6.3 \%$. Gypsum content is very low and varied from 0.01 to $1.8 \%$. Cation exchange capacity varied in narrow limit between 0.26 and 7.95 Cmole $\mathrm{kg}-1$, while ESP values ranged from 3.89 to $23.82 \%$.

\section{3- Soils of wadi deposits (DF121)}

Wadi deposits sub geomorphic unit is located in the North and South borders with almost flat surface covering approximate area of 402.8 km2 (96672 feddans). It is represented by profiles 3 and 12. This sub geomorphic unit was probably deposited with the drainage from the Eastern plateaus throughout the different rock structures. The soil relief is almost flat with moderately deep soil profile. Soil dry colour varied from light brown (7.5 YR 4/6) to pale brown (10 YR 6/3), while moist colour ranged between dark brown (7.5 YR 3/4) and brown (10 YR 5/3). Soil texture varied from sandy loam to clay with very few fine gravels. The soil structure is undeveloped where weak sub angular blocky structure. Soils have a consistence varied from slightly sticky to very sticky and slightly plastic to very plastic.

The data in Table (3) showed that, $\mathrm{pH}$ values ranged from 7.22 to 8.18 indicating neutral to moderately alkaline soil reaction. ECe values ranged from slightly to very extremely saline as revealed by ECe values that varied from 6.22 to $\mathbf{1 1 5 . 5}$ dSm-1. Organic matter content is very low not exceeds $\mathbf{0 . 4 8} \%$. CaCO3 content varied from 9.24 to $24.84 \%$. Gypsum content is very low and varied from 0.06 to $1.23 \%$. The Cation exchange capacity (CEC) ranged from 5.82 to 25.20 Cmole $\mathrm{kg}-1$ and ESP varied from 0.01 to $29.94 \%$.

\section{4- Soils of playa (DF131)}

This sub unit is delineated along the north and south western part of El-Kharga Oases covering approximate area of 481. Km2 (116064 feddans) and representing by profiles 5,6 and 20 . The morphological description (Table 1 ) reveal that, the soil relief is almost flat with deep soil profile (>150 m). Soils of playa has dry colours ranged from reddish yellow (7.5 YR 6/6) to yellow (10 YR 7/6). The moist colours vary from reddish yellow (7.5 YR 6/6) to grey (10 YR 6/1). Soil texture varied from sand to clay with gravel content less than $25 \%$ by volume. These soils were structure less (single grains) and massive. The consistence was non sticky to very sticky and non-plastic to very plastic. 
Data in Table (3) reveal that, soil reaction in generally neutral to moderately alkaline having $\mathrm{pH}$ values ranged from 7.02 and 8.4. The studied soils are characterized by very slightly saline to very extremely saline, where the ECe values ranged between 3.87 and 1120 dS $\mathrm{m}-1$. Organic matter content in generally very low not exceeds $0.43 \%$. The total carbonate content was very low due to the sandstone origin. Gypsum content is very low and varied from 0.01 to $1.04 \%$. The CEC values showed a relative increase in the deepest layers of soil profiles due to the relatively high clay content. It varied from 0.064 to 32.06 Cmole $\mathrm{kg}$-1, while ESP values ranged between 5.25 to $60.48 \%$.

\section{5- Soils of Sabkha (DF141)}

This sub geomorphic unit located in the middle of El-Kharga Oases with an area of about $20 \mathrm{~km} 2$ (4800 feddans). The soils of this sub unit are represented by profiles 13, 14, 15, 17 and 19. Topographically, the landscape is almost flat with moderately deep to deep soil profiles. Soil dry colour varied from reddish grey (5 YR 5/2) to very pale brown (10 YR 8/2). Moist colour ranged between dark reddish grey (5 YR 4/2) and light grey (10 YR 7/2). Soil texture class varied from sand to clay with single grain and massive structure respectively. Soil consistence ranged from non-sticky to very sticky and non-plastic to very plastic. Table (3) reveals that, these soils are slightly acid to moderately alkaline where $\mathrm{pH}$ values varied from 6.35 to 8.1. ECe values varied between 2.64 and $125.9 \mathrm{dSm}^{-1}$ indicating very slightly saline to very extremely saline soil. Organic matter content was very low and ranged from 0.03 to $1.15 \%$.

Calcium carbonate content was very low and varied in narrow limit from 0.14 to $6.12 \%$, Gypsum content varied from 0.10 to $8.42 \%$. Cation exchange capacity ranged from 0.26 to $37.36 \mathrm{Cmole} \mathrm{kg}^{-1}$. ESP values varied from $0.61-60.70 \%$.

The spatial distribution pattern of soil salinity and calcium carbonate content in the studied area of El- Kharga Oases are shown in Figs. (6) and (7).

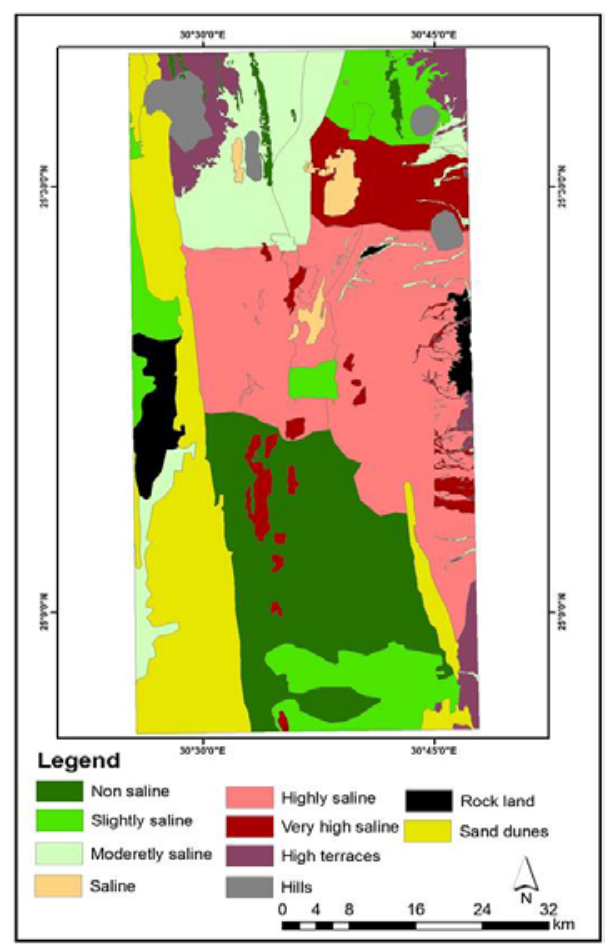

Fig (6): Spatial distribution of salinity status in the studied area 


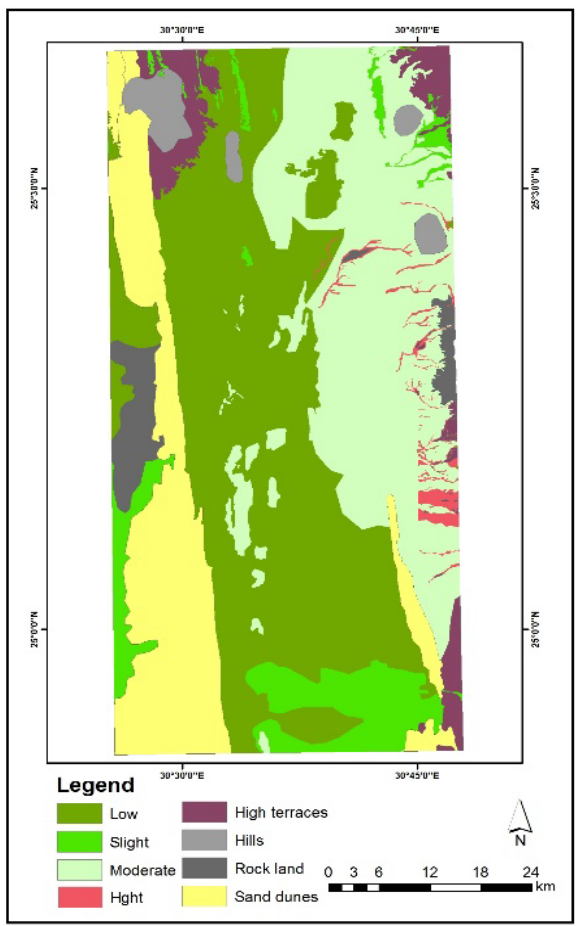

Fig (7): Spatial distribution of calcareous features in the studied area

\section{Soil classification:}

Classification for the studied soils (Table, 4 and Fig. 8) of El-Kharga Oases represented by different soil profiles based on the morphological, physical and chemical characteristics was done according to Soil Survey Staff (1999 and 2014).

Accordingly, the studied soils could be classified up to sub great group levels into three orders, namely, Vertisols, Aridisols and Entisols as presented in Table (4) and Fig (8).

\section{Land Evaluation}

The parametric land evaluation system, undertaken by Sys and Verheye (1978) and Sys et al., (1991) is applied to identifying the soil limitations and their intensities as well as the land capability classes in the to the current and potential status.

\section{Current land Capability:}

The capability indexes (Ci) for the studied soil profiles are presented in Table (5) and Fig (9). The results reveal that, the studied soil profiles are placed between the fair soils (III) and very poor soil $(\mathrm{N})$.

1- Soils of grade III (fair soils): These soils are found in Pediplain unit which represented by profiles $1,8,10$ and 11 and in Sand Dunes (profiles 2,4,16, and 18) as well as in Sabkha (profiles 14 and 19). The soils of this grade are affected by moderate to severe intensity of soil texture and salinity and alkalinity and slightly to moderately intensity of $\mathrm{CaCO}_{3}$ and gypsum contents, this grade representing $45 \%$ of the studied area.

2. Soils of grade IV (poor soils): The soils of this grade are found in Pediplain (profiles 7,9 and 21), playa (profiles 5,6 and 20), Wadi deposits (profiles 3 and 12) and Sabkha (profiles 13 and 17). Their $\mathrm{Ci}$ values varied from 21.9 to $39.7 \%$ This grade is representing $50 \%$ of the studied area. The soils of this grade are suffering from some soil limitations i.e. soil texture, $\mathrm{CaCO}_{3}$, gypsum contents as well as salinity and alkalinity with different intensity degrees. 
Table (4): Soil classification categories of the studied profiles.

\begin{tabular}{|c|c|c|c|c|}
\hline Order & Sub order & Great group & Sub group & Prof. No. \\
\hline Vertisols & Torrerts & Haplotorrerts & Chromic Haplotorrerts & 1 \\
\hline \multirow{4}{*}{ Aridisols } & \multirow{4}{*}{ Salids } & \multirow{4}{*}{ Haplosalids } & Typic Haplosalids & $\begin{array}{c}6 \\
7 \\
14 \\
17 \\
19 \\
21\end{array}$ \\
\hline & & & Gypsic Haplosalids & 15 \\
\hline & & & Calcic Haplosalids & $\begin{array}{c}9 \\
12 \\
20\end{array}$ \\
\hline & & & Typic Haplocalsids & 8 \\
\hline \multirow{6}{*}{ Entisols } & Fluvents & Torri-Fluvents & Typic- Torrifluvents & 5 \\
\hline & \multirow{2}{*}{ Orthents } & \multirow{2}{*}{ Torri-orthents } & Typic-Torriorthents & 11 \\
\hline & & & Typic- Torriorthents & 3 \\
\hline & \multirow{3}{*}{ Psamments } & Torri-psamments & Typic- Torripsamments & 16,18 \\
\hline & & \multirow{2}{*}{ Quartzi-psamments } & \multirow{2}{*}{$\begin{array}{l}\text { Typic Quartzipsam- } \\
\text { ments }\end{array}$} & 10 \\
\hline & & & & $2,4,13$ \\
\hline
\end{tabular}

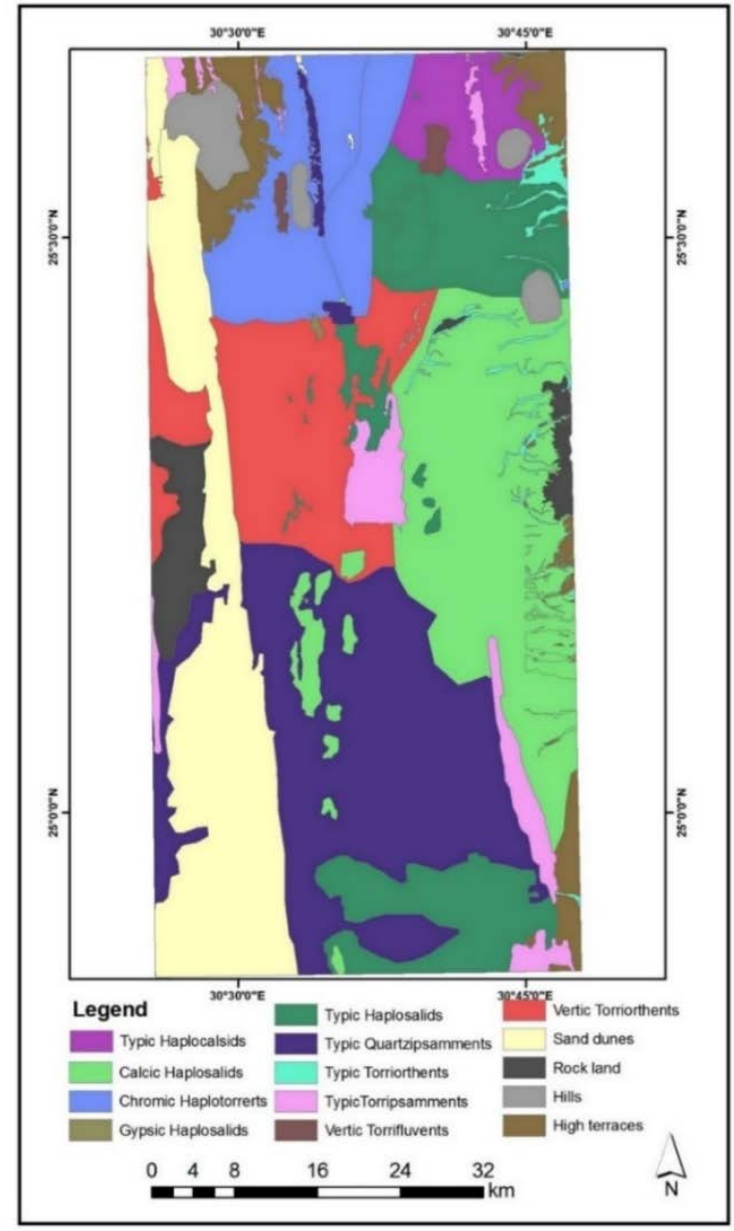

Fig (8): Soil classification of the studied area 


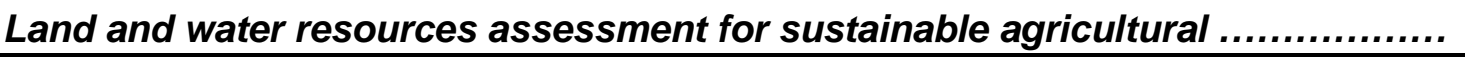

Table (5): Current and potential land Capability classes for the studied soil

\begin{tabular}{|c|c|c|c|c|c|c|c|c|c|c|c|c|c|c|c|}
\hline \multirow{3}{*}{$\begin{array}{l}\text { Prof. } \\
\text { No. }\end{array}$} & \multicolumn{2}{|c|}{$\begin{array}{c}\text { Topogra } \\
\text { phy }(t)\end{array}$} & \multicolumn{2}{|c|}{$\begin{array}{l}\text { Wetness } \\
(w)\end{array}$} & \multicolumn{5}{|c|}{$\begin{array}{l}\text { Rating of Soil Physical } \\
\text { Characteristics }\end{array}$} & \multirow{2}{*}{\multicolumn{2}{|c|}{$\begin{array}{l}\text { Salinity/AI } \\
\text { kalinity }\end{array}$}} & \multirow{2}{*}{\multicolumn{2}{|c|}{$\begin{array}{c}\text { Current } \\
\text { Capability }\end{array}$}} & \multirow{2}{*}{\multicolumn{2}{|c|}{$\begin{array}{l}\text { Potential } \\
\text { Capability }\end{array}$}} \\
\hline & \multirow{2}{*}{ CS } & \multirow{2}{*}{ PS } & \multirow{2}{*}{ CS } & \multirow{2}{*}{ PS } & \multirow{2}{*}{$\begin{array}{c}\text { Dep } \\
\text { th }\end{array}$} & \multicolumn{2}{|c|}{ Texture } & \multirow{2}{*}{$\begin{array}{c}\mathrm{Li} \\
\mathrm{me}\end{array}$} & \multirow{2}{*}{$\begin{array}{l}\text { Gyp } \\
\text { sum }\end{array}$} & & & & & & \\
\hline & & & & & & $\mathrm{CS}$ & PS & & & CS & PS & $\mathrm{Ci}$ & Class & $\mathrm{Ci}$ & Class \\
\hline 1 & 95 & 100 & 100 & 100 & 100 & 85 & 90 & 90 & 90 & 85 & 100 & 55.6 & S3 & 72.9 & S2 \\
\hline 2 & 90 & 100 & 100 & 100 & 100 & 50 & 70 & 100 & 90 & 100 & 100 & 40.5 & S3 & 63.0 & S2 \\
\hline 3 & 100 & 100 & 100 & 100 & 60 & 65 & 80 & 90 & 90 & 85 & 100 & 26.9 & S4 & 38.9 & S4 \\
\hline 4 & 100 & 100 & 100 & 100 & 100 & 50 & 70 & 100 & 90 & 100 & 100 & 45.0 & S3 & 63.0 & S2 \\
\hline 5 & 100 & 100 & 100 & 100 & 100 & 50 & 70 & 90 & 90 & 98 & 100 & 39.7 & S4 & 56.7 & S3 \\
\hline 6 & 100 & 100 & 100 & 100 & 100 & 50 & 70 & 100 & 90 & 80 & 100 & 36.0 & S4 & 63.0 & S2 \\
\hline 7 & 100 & 100 & 100 & 100 & 100 & 60 & 80 & 90 & 90 & 45 & 80 & 21.9 & S4 & 51.8 & S3 \\
\hline 8 & 90 & 100 & 100 & 100 & 100 & 60 & 80 & 100 & 90 & 90 & 100 & 43.7 & S3 & 72.0 & S2 \\
\hline 9 & 100 & 100 & 100 & 100 & 100 & 65 & 80 & 90 & 90 & 75 & 100 & 39.5 & S4 & 64.8 & S2 \\
\hline 10 & 100 & 100 & 100 & 100 & 100 & 50 & 70 & 90 & 90 & 100 & 100 & 40.5 & S3 & 56.7 & S3 \\
\hline 11 & 100 & 100 & 100 & 100 & 100 & 65 & 80 & 100 & 90 & 75 & 100 & 43.9 & S3 & 72.0 & S2 \\
\hline 12 & 100 & 100 & 100 & 100 & 60 & 90 & 100 & 90 & 90 & 75 & 100 & 32.8 & S4 & 48.6 & S3 \\
\hline 13 & 100 & 100 & 100 & 100 & 100 & 50 & 70 & 90 & 90 & 98 & 100 & 39.7 & S4 & 56.7 & S3 \\
\hline 14 & 100 & 100 & 100 & 100 & 100 & 70 & 80 & 90 & 90 & 75 & 100 & 42.5 & S3 & 64.8 & S2 \\
\hline 15 & 100 & 100 & 100 & 100 & 60 & 65 & 80 & 100 & 100 & 45 & 80 & 17.6 & N1 & 38.4 & S4 \\
\hline 16 & 100 & 100 & 100 & 100 & 100 & 60 & 80 & 100 & 90 & 75 & 100 & 40.5 & S3 & 72.0 & S2 \\
\hline 17 & 100 & 100 & 100 & 100 & 100 & 90 & 100 & 100 & 90 & 45 & 80 & 36.5 & S4 & 72.0 & S2 \\
\hline 18 & 100 & 100 & 100 & 100 & 100 & 60 & 80 & 100 & 90 & 85 & 100 & 45.9 & S3 & 72.0 & S2 \\
\hline 19 & 100 & 100 & 100 & 100 & 100 & 100 & 100 & 90 & 100 & 58 & 80 & 52.2 & S3 & 72.0 & S2 \\
\hline 20 & 75 & 100 & 100 & 100 & 100 & 90 & 100 & 90 & 90 & 45 & 80 & 24.6 & S4 & 64.8 & S2 \\
\hline 21 & 100 & 100 & 100 & 100 & 100 & 90 & 100 & 90 & 90 & 45 & 80 & 32.8 & S4 & 64.8 & S2 \\
\hline & & & & & & & & I. E & ar & 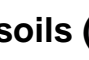 & $00-10$ & 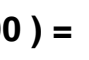 & & S1 & \\
\hline & $\begin{array}{r}\text { rent } \mathrm{C} i \\
\text { (CS }\end{array}$ & apabil & & & $\begin{array}{l}\text { Potenti } \\
\text { apabil } \\
\text { (PS) }\end{array}$ & & & II. & Good & solls & $60-7$ & 9) = & & S2 & \\
\hline S2 & S3 & S4 & N1 & S2 & S3 & S4 & & III. & Fair sc & ils (4 & 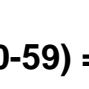 & S3 & & S3 & \\
\hline 0.00 & 47.62 & 47.62 & 4.76 & 66.67 & 23.81 & 9.52 & & IV. F & Poor & (5) & J & 44 & & S4 & \\
\hline & 100. & & & & 100.00 & & & V. V & ery po & or so & I (10- & 19) = & N1 & N1 & \\
\hline$C S=c$ & rre & . & Iys & & & & & VI. N & Von ag & ricu & re so & il $<10$ & $0=\mathrm{N} 2$ & N2 & \\
\hline$S=r$ & ten & ial ro & & & & & & & & & & & & & \\
\hline $\mathrm{Ci}=\mathrm{C}$ & apabil & ity in & dex & & & & & * $S$ & s et & 199 & art 2 & & & & \\
\hline
\end{tabular}




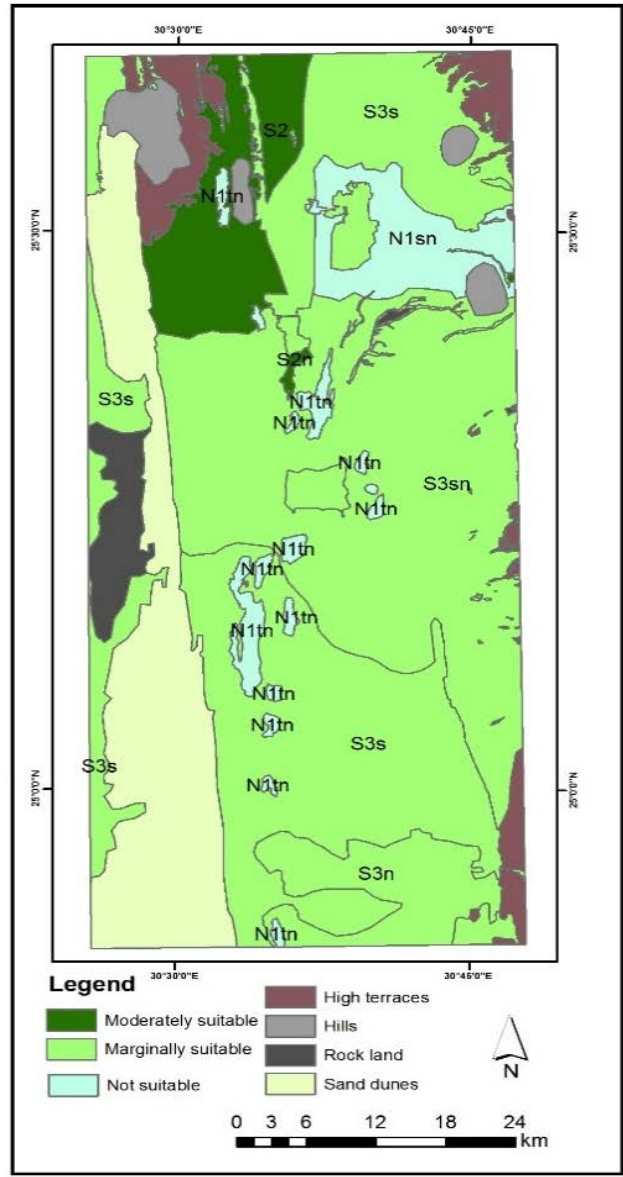

Fig. (9): Current Soil capability of the studied area for irrigated agriculture.

3- Soils of grade $\mathbf{N}$ (very poor soils): The soils of this grade are mainly found in Sabkha unit (profile 15). These soils are affected by moderate to severe limitations. The dominant limitations are soil texture, soil profile depth and salinity and alkalinity. This grade of soils is representing $5 \%$ of the studied area.

\section{Potential land Capability:}

For raising the potential land capability of El-Kharga soils, soil improvement practices should be carried out such as land levelling and removing the excess of soluble salts through applying the leaching requirements under an efficient drainage ditches for soils suffering from salinity. Such management practices will be corrected the ratings of soil potential suitability class for the majority of the studied soils, and potential land capability becomes as follows.

1- Soils of grade II (good soils): The Ci values of this grade varied from 63 to $72.9 \%$ and found in Pediplain soils (profiles 2,8,9, 11 and 21), Sand dunes (profiles Nos. 2,4,16 and 18), Playa (profiles 6 and 20) and Sabkha (profiles 14,17 and 19). The soils of grade II are representing $65 \%$ of the studied area (Table, 5 and Fig 10).

2- Soils of grade III (fair soils): The $\mathrm{Si}$ values of this grade ranged from $\mathbf{4 8 . 6}$ to $56.7 \%$ and found in Pedi plain (profiles 7 and 10), playa (profile 5), wadi deposits (profile 12), and sabkha (profile 13). Soils of this grade (III) are representing $25 \%$ of the studied area. 


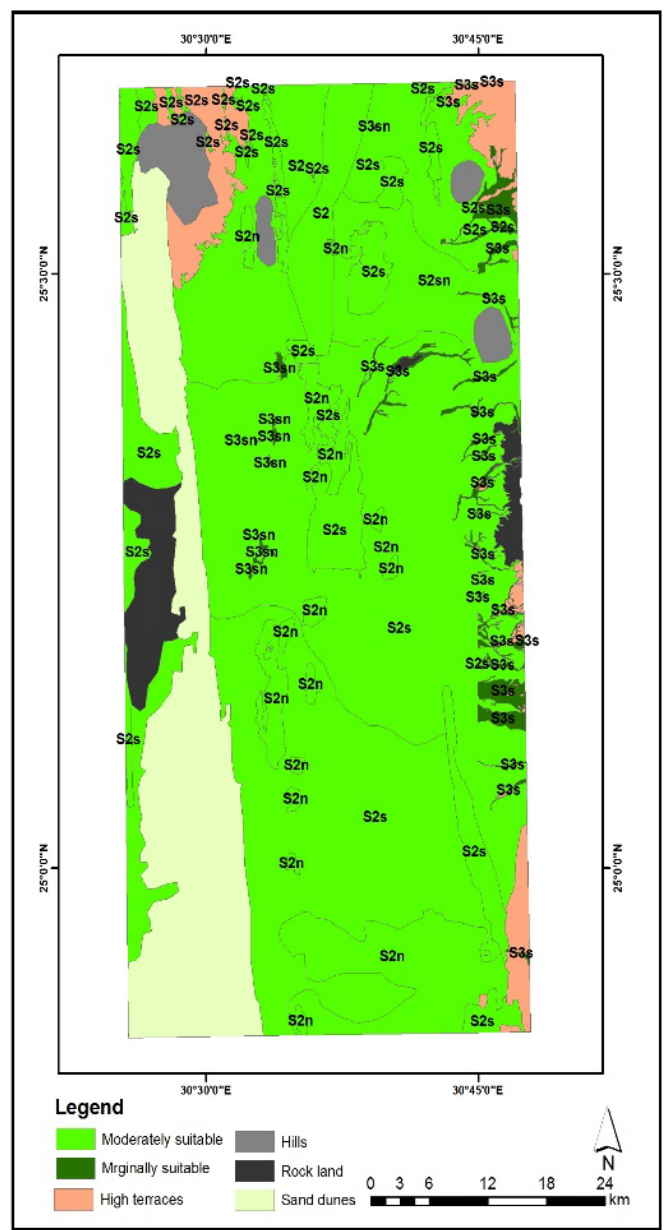

Fig. (10): Potential Soil capability of the studied area for irrigated agriculture.

3- Soils of grade IV (poor soils): The soils of this grade have Si values less than $38.9 \%$ and found in Wadi deposits (profile 3) and Sabkha (profile 15). The soils of this grade are representing $10 \%$ of the studied area.

\section{Land suitability for specific crops}

Current and potential soil suitability for cultivation of specific main crops are assessed in the studied areas of ElKharga Oases according to Sys et al., (1993) The results are shown in Table (6).

\section{1- Current land suitability:}

Most of the studied soils $(70.60 \%)$ are not suitable for cultivation of studied crops in the current situation. Only $29.4 \%$ of these soils are marginally suitable for these crops as follows:

- Soils of Pedi plain for alfalfa, green pepper, olives and mango.

- Soils of sand dunes for onion, cabbage, green pepper, citrus, olives and mango.

- Soils of playa for olives and mango.

- Soils of wadi deposits for barley, wheat, guava, and olives.

- Soils of sabkha for alfalfa, barley, wheat, guava, and olives.

\section{2- Potential land suitability:}

Only $1.18 \%$ of the studied area could be considered as highly suitable for olives in the soils of playa. Also, $64.7 \%$ of the studied area could be developed to moderately suitable (S2) for cultivation of the studied crops as follows: 
Table (6): Current and potential Suitability classes of the studied soil profiles for specific crops.

\begin{tabular}{|c|c|c|c|c|c|c|c|c|c|c|}
\hline \multirow[b]{2}{*}{ Crops } & \multicolumn{5}{|c|}{ Current suitability } & \multicolumn{5}{|c|}{ Potential suitability } \\
\hline & $\begin{array}{l}\frac{5}{\pi} \\
\frac{\pi}{\frac{\pi}{2}} \\
\frac{0}{0} \\
0\end{array}$ & 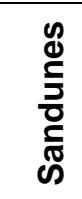 & $\frac{\widetilde{\pi}}{\frac{\pi}{\sigma}}$ & $\begin{array}{l}0 \\
\frac{0}{0} \\
0 \\
\frac{0}{0} \\
0 \\
3 \\
3\end{array}$ & 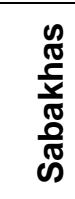 & $\begin{array}{l}\frac{.}{\pi} \\
\frac{\pi}{2} \\
\frac{\pi}{2} \\
\frac{d}{\alpha}\end{array}$ & 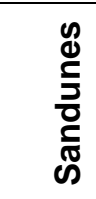 & $\frac{\pi}{\frac{\pi}{\sigma}}$ & $\begin{array}{l}\frac{0}{0} \\
\frac{1}{0} \\
0 \\
\frac{0}{0} \\
\frac{0}{3}\end{array}$ & 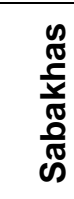 \\
\hline Alfalfa & S3 & S3 & N1 & N1 & S3 & $\mathrm{S} 2$ & S2 & S2 & S3 & S2 \\
\hline Barley & N1 & N1 & N1 & S3 & S3 & $\mathrm{s} 2$ & S2 & S2 & s2 & S2 \\
\hline Peans & N1 & N2 & N2 & N2 & N2 & S3 & S3 & S3 & N1 & S3 \\
\hline Cowpea & N1 & N1 & N1 & N1 & N1 & $\mathrm{S} 2$ & S2 & S2 & S3 & $\mathrm{S2}$ \\
\hline Pea & N1 & N1 & N1 & N1 & N1 & s2 & S2 & S2 & S3 & S2 \\
\hline Sunflower & N1 & N1 & N1 & N2 & N1 & S3 & S2 & S2 & N1 & S2 \\
\hline Wheat & N1 & N1 & N1 & S3 & S3 & $\mathrm{S} 2$ & S2 & S2 & $\mathrm{s} 2$ & S2 \\
\hline Maize & N1 & N1 & N1 & N1 & S3 & S2 & S2 & S2 & S3 & S2 \\
\hline Tomato & N1 & N1 & N1 & N2 & N1 & $\mathrm{S} 2$ & S2 & S3 & N1 & S3 \\
\hline Potato & N1 & N1 & N1 & N1 & S3 & $\mathrm{S} 2$ & S2 & S3 & S3 & $\mathrm{S} 2$ \\
\hline Onion & N1 & S3 & N1 & N1 & N1 & $\mathrm{S} 2$ & S2 & S3 & S3 & S3 \\
\hline Cabbage & S3 & S3 & N1 & N1 & S3 & S2 & S2 & S2 & S3 & S2 \\
\hline $\begin{array}{l}\text { Green } \\
\text { Pepper }\end{array}$ & S3 & S3 & N1 & N1 & N1 & $\mathrm{S} 2$ & S2 & S2 & N1 & S3 \\
\hline Citrus & N1 & S3 & N1 & N2 & N1 & S3 & S2 & S3 & N2 & S3 \\
\hline Guava & N1 & N1 & N1 & S3 & S3 & $\mathrm{S} 2$ & S2 & S2 & $\mathrm{S2}$ & $\mathrm{S2}$ \\
\hline Olives & S3 & S3 & S3 & S3 & S3 & $\mathrm{S} 2$ & S2 & s1 & $\mathrm{s} 2$ & S2 \\
\hline Mango & S3 & S3 & S3 & N2 & N1 & $\mathrm{s} 2$ & S2 & S2 & N1 & S3 \\
\hline
\end{tabular}

\begin{tabular}{|c|c|c|c|c|c|c|c|c|c|}
\hline \multicolumn{3}{|l|}{$S$} & \multicolumn{2}{|l|}{$\mathrm{N}$} & \multicolumn{3}{|l|}{ S } & \multicolumn{2}{|l|}{$\mathbf{N}$} \\
\hline S1 & S2 & S3 & N1 & N2 & S1 & S2 & S3 & N1 & N2 \\
\hline 0.00 & 0.00 & 30.59 & 60.00 & 9.41 & 1.18 & 65.88 & 25.88 & 5.88 & 1.18 \\
\hline \multicolumn{3}{|c|}{30.59} & \multicolumn{2}{|l|}{69.41} & \multicolumn{3}{|c|}{92.94} & \multicolumn{2}{|l|}{7.06} \\
\hline \multicolumn{5}{|c|}{100.00} & \multicolumn{5}{|c|}{100.00} \\
\hline
\end{tabular}

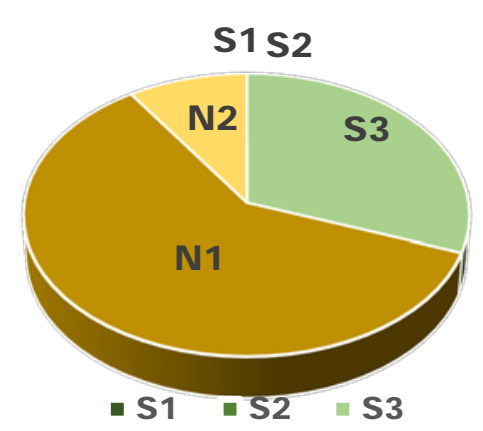

Different classes of the current land suitability for crops

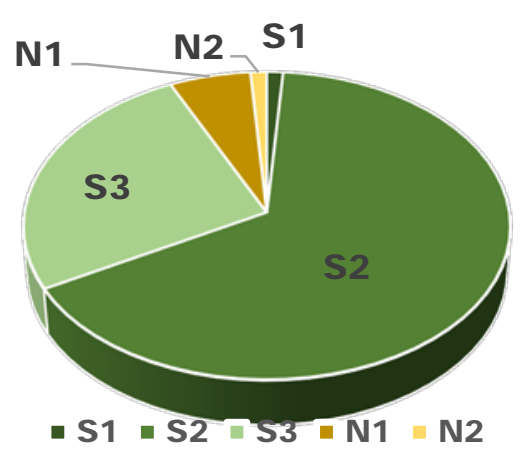

Different classes of the potential land suitability for crops 
- Soils of Pedi plain for alfalfa, barley, cowpea, pea, wheat, maize, tomato, potato, onion, cabbage, green pepper, guava, olives and mango.

- Soils of Sand dunes for alfalfa, barley, cow pea, sunflower, wheat, maize tomato, potato, onion, cabbage, green pepper, citrus, guava, olives and mango.

- Soils of Playa for alfalfa, barley, cowpea, pea, sunflower, wheat, maize, cabbage, green pepper, guava, and mango.

- Soils of Wadi deposits for barley, guava and olives.

- Soils of Sabkha for guava and olives.

Moreover, about $25.9 \%$ from the studied area could be considered as marginally suitable (S3) for crops as follow:

- Soils of Pedi plain for beans, sun flower, and citrus.

- Soils of sand dunes for beans.

- Soils of playa for beans, tomato, potato, onion and citrus.

- Soils of wadi deposits for alfalfa, cowpea, pea, maize onion and cabbage.

Soils of sabkha for beans, tomato, onion, green pepper, citrus and mango. Finally, some soils of Wadi deposits $(8.25 \%)$ are not suitable (N2) for beans, sunflower, wheat, tomato, green pepper, citrus and mango.

\section{Quality of groundwater}

Irrigation water in the study area is mainly ground water. To study the quality of this water. Ten ground water samples were collected from wells found in this area. The samples were chemically analysed and the results were presented in Table (7). Data in Table (7) revealed the following features:

Water reaction $(\mathrm{pH})$ : The reaction of water samples ranged from utra-acid $\mathrm{(pH}$ 3.47) in the north of El-Kharga to slightly alkaline (pH 7.83) in Max Qibly.

Water salinity (EC): The water salinity of the study area ranged from non-saline $\left(0.48 \mathrm{dSm}^{-1}\right)$ in the east of El-Kharga to extremely saline $\left(119 \mathrm{dsm}^{-1}\right)$ in south Bolaqe. Mandel and Shiftan (1981), found that, the water samples of El-Monira, Rakoda village, Edan village and East elKharga are fresh water. While the samples were fresh to brackish in the north of El Kharga, Paris, and El-Torfiya village and brackish in Ezbit Mostafa, south Bolaqe and Max Qibly.

Total dissolved solids (TDS): According to the classification of Hem (1985), the ground water of investigated area (based on their TDS) varied from fresh in El-Monira, Rakda village, Eden village and East El-kharga, fresh to slightly saline (brackish) in the north of ElKharga, Paris and El-Torfiya village. It is extremely saline in Ez. Mostafa, South Bolaqe and Max Qibly.

Soluble cations in the studied groundwater samples follow three orders. The first order $\mathrm{Ca}^{++}>\mathrm{Na}^{+}>\mathrm{Mg}^{++}>\mathrm{K}^{+}$. The second order $\mathrm{Mg}++>\mathrm{Na}+>\mathrm{Ca}++>\mathrm{K}+$. The third order $\mathrm{Na}^{+}>\mathrm{Ca}^{++}>\mathrm{Mg}^{++}>\mathrm{K}^{+}$. The anonic composition of the studied groundwater samples follow the order $\mathrm{Cl}^{-}$ $>\mathrm{So}_{4}{ }_{4}>\mathrm{HCO}_{3}$ except for the groundwater samples of Ez. Mostafa, North El-kharga, South Bolaqe and Paris where the anionic follow the order $\mathrm{So}_{4}{ }_{4}>\mathrm{Cl}>\mathrm{HCO}_{3}$. The concentration of the major cations and anions are lower than the maximum stander and limits of the World Health Organization "WHO" (1984) except for the samples of Ez. Mostafa, South Bolaqe and Max Qibly.

Sodium Adsorption Ratio (SAR): Data in Table (7) showed that, most of the studied ground water samples have SAR value $<10$ and could be characterized as excellent suitable water for irrigation except the ground water samples of Ez Mostafa, North El-kharga and Max Qibly that have SAR values >10. 
Table (7): Chemical analysis of ground water samples in the studied area.

\begin{tabular}{|c|c|c|c|c|c|c|c|c|c|c|}
\hline properties & $\begin{array}{l}\text { East EI } \\
\text { Kharga }\end{array}$ & $\begin{array}{c}\text { Eden } \\
\text { village }\end{array}$ & $\begin{array}{l}\text { Rakda } \\
\text { villige }\end{array}$ & $\begin{array}{c}\text { EI } \\
\text { Tarfiya }\end{array}$ & $\begin{array}{l}\text { Max } \\
\text { Qibly }\end{array}$ & Paris & $\begin{array}{l}\text { South } \\
\text { Bolaqe }\end{array}$ & $\begin{array}{l}\text { North } \\
\text { EI } \\
\text { Kharga }\end{array}$ & $\begin{array}{c}\text { EI } \\
\text { Monira }\end{array}$ & $\begin{array}{c}\text { Ez } \\
\text { Mostafa }\end{array}$ \\
\hline PH & 6.52 & 6.96 & 7.38 & 7.26 & 7.83 & 5.98 & 6.66 & 3.42 & 7.05 & 7.1 \\
\hline EC dS/m & 0.48 & 0.54 & 0.84 & 3.13 & 302.6 & 3.32 & 119 & 4.1 & 0.57 & 111.4 \\
\hline TDS ppm & 307.2 & 345.6 & 537.6 & 2003.2 & 65664 & 2124.8 & 7616 & 2624 & 364.8 & 71424 \\
\hline \multicolumn{11}{|c|}{ Anions (meq/l) } \\
\hline $\mathrm{CO}=$ & -- & -- & -- & -- & 0.1 & -- & -- & -- & -- & -- \\
\hline HCO3- & 3 & 2.4 & 3 & 9.4 & 13 & 1 & 3.8 & 0 & 2.8 & 1 \\
\hline $\mathrm{Cl}^{-}$ & 2 & 2 & 4 & 13 & 2270 & 15 & 3330 & 10 & 4 & 1580 \\
\hline SO4= & 0.04 & 0.76 & 0.55 & 10.17 & 592.9 & 24.89 & 333.46 & 44.2 & 1 & 2880.02 \\
\hline \multicolumn{11}{|c|}{ Cations (meq/l) } \\
\hline $\mathrm{Ca}++$ & 1.78 & 2.33 & 3.33 & 7.22 & 66.67 & 13.89 & 113.33 & 22.22 & 2.78 & 61.11 \\
\hline Mg++ & 0.9 & 0.35 & 0.88 & 5.93 & 1380.73 & 11.37 & 850.87 & 14.62 & 1.96 & 1633.6 \\
\hline $\mathrm{Na}+$ & 1.34 & 1.25 & 1.81 & 18.08 & 1171.99 & 12.78 & 1321.56 & 14.65 & 2.09 & 2618.2 \\
\hline $\mathrm{K}+$ & 1.02 & 1.23 & 1.53 & 1.34 & 56.55 & 2.81 & 158.15 & 2.71 & 0.97 & 151.12 \\
\hline SAR & 1.16 & 1.06 & 1.25 & 7.05 & 43.37 & 3.6 & 91.28 & 3.41 & 1.36 & 89.94 \\
\hline RSC & 0.32 & -0.28 & -1.21 & -3.75 & -1434 & -24.26 & -415.42 & 36.84 & -1.94 & -1690.7 \\
\hline *t.w.c & C2-S1 & C2-S1 & C2-S1 & C4-S1 & C4-S1 & C4-S1 & C4-S1 & C4-S1 & C4-S1 & C4-S4 \\
\hline \multicolumn{11}{|c|}{ Trace elements (ppm) } \\
\hline B & -- & -- & -- & 0.28 & 4.2 & -- & 2.94 & 0.37 & -- & 3.67 \\
\hline $\mathrm{Fe}$ & 2.84 & 3 & 4.52 & 2.5 & 2.15 & 2.32 & 3.21 & 2.85 & 5 & 4.87 \\
\hline Mn & 2.41 & 2.45 & 4.11 & 2.41 & 2 & 2.98 & 2.98 & 2.57 & 4.41 & 4.75 \\
\hline Zn & 0.3 & 0.24 & 0.49 & 0.21 & 0.35 & 0.45 & 0.55 & 0.39 & 0.47 & 0.58 \\
\hline $\mathrm{Cu}$ & 0.97 & 1 & 0.75 & 1.02 & 0.4 & 1.2 & 1 & 0.8 & 0.31 & 0.65 \\
\hline Hardness & 2.68 & 2.68 & 4.21 & 13.15 & 1447.4 & 25.26 & 964.2 & 36.84 & 4.74 & 1994.7 \\
\hline
\end{tabular}

Residual sodium carbonate (RSC): Data in Table (7) indicated that, the calculate RSC values for all the studied groundwater samples has $<1.25 \mathrm{meq} / \mathrm{l}$ RSC (Class 1 ) which is good quality and suitable for using in irrigation for all types of soils.

Richards, (1954) divided the water quality into classes C1, C2, C3, and C4 according to its salinity and into S1, S2, S43 and S4, according to its SAR. The studied ground water samples of the Rakoda village, Eden village and East ElKharga lies in the field of C2-S1. This indicates that, these waters are good and suitability for irrigation purposes under normal condition. Groundwater samples of El-Monira, North El-Kharga, South 
Bolaqe, Paris, Max Qibly and El-Tarfiya are belong to class (C4-S1) which characterized by very high salinity hazards and low sodium water. while groundwater sample of Ez. Mostafa is belonging to class (C4-S4) having very highly saline and very high SAR. These two classes of water are not suitable for irrigation under ordinary conditions. It may be used under special circumstances, such as, the soil must be permeable, drainage must be adequate, irrigation must be applied in excess to provide considerable leaching and selection of high salt tolerant crops.

Trace elements: Date in Table (7) showed that, the values of trace elements in the studied groundwater samples varied from 0.28 to $4.62 ; 2.15$ to $5.0 ; 2.0$ to 4.75; 0.21 to 0.58 and 0.4 to $1.2 \mathrm{meq} / \mathrm{l}$ for $\mathrm{B}, \mathrm{Fe}, \mathrm{Mn}, \mathrm{Zn}$ and $\mathrm{Cu}$ respectively. The relatively high content of $\mathrm{B}, \mathrm{Cu}$ and $\mathrm{Mn}$ is related to the geological nature of the study area which enriched by these elements in their sedimentary secession (CONOCO, 1987).

Hardness (TH): Hardness of water is a property allocable to dissolved $\mathrm{Ca}++$ and $\mathrm{Mg++}$ in water. The total hardness is related to the total quantities of $\mathrm{Ca}++$ and Mg++ in water, while permanent hardness is due to the quantities of $\mathrm{Ca++}$ and $\mathrm{Mg++}$ that are still soluble in water after removing temporary hardness by boiling the water. Based on the amount of dissolved $\mathrm{Ca}++$ and $\mathrm{Mg}++$ in ground water, its handiness can be divided into five categories starting from very soft whose $\mathrm{Ca}++$ and $\mathrm{Mg}++$ constituents are not more than $1.5 \mathrm{meq} / \mathrm{l}$, and ending with very hard that contain more than $9 \mathrm{meq} / \mathrm{l}$ According. The studied ground water samples range between soft to very hand where total hardness values ranged between 2.68 and $1694.7 \mathrm{meq} / \mathrm{l}$.

\section{REFERENCES}

ASRT (1989). Encyclopaedia of the Western Desert of Egypt. Academy of Scientific Research an Technology $4^{\text {th }}$ part, Desert Research Inst. Egypt.

Burt, Rebecca, Ed. (2004). Soil Survey Laboratory Methods manual, soil Survey Investigations Report No. 42. V. 4, Natural Resources Conservation Service (NRCS) - USDA, Lincoln, Nebraska.

CLAC (2016)" Central Laboratory for Agriculture of Climate. Agric. Res. Centre, Giza, Egypt.

CONOCO "Continental Oil Company" (1987). Geologic Map of Egypt. Egyptian General Authority for Petroleum (UNESCO joint map project), 20 sheets, scale 1:500 000. Cairo, Egypt.

DRI “Desert Research Institute” (1983). New Valley Region., Semi - detailed Survey. Land Master plan. GARPD. Cairo, Egypt.

Dobos, F., B. Norman, W. Bruee, M. Luca, J. Chris and M. Enka (2002). The use of DEM and saltellite images for regional scale soil database. 17th word congress of soil science (WCSS) 14-21 August 2002 Bangkok, Thailand.

Egyption Geological Survey (1999). The Phanerozoic geological of Egypt, A Geodynamic Approach, special publication No. 76.

El-Shazly-E.M. (1976). Geology and ground water potential of Kharga and Dakhla Oases area, Western Desert, Egypt from NASA Landsat-1 Satellite images. Academy of Scientific Research, Cairo.

ESRI (2004). “Arc Map version 10.4 user manual", Redlands, CA, USA.

ESRI (2014). "Earth Science Reference Tables" Arc Map version 10.4 user manual Red land, CA, USA. 
Ezz El- Deen, H. M. (1996). Uses of Geophysical, hydrogeological Method and application of geographic information system for evaluation the development of Paris area. New Valley, Egypt. Ph.D. Thesis Fac. of Sci. Ain Shams univ., Egypt.

Garmin Co. (1997). Owner's manual and references. Olathe, KS. USA.

FAO (1985). Water quality for Agriculture. FAO irrigation and drainage paper No. 29, Rev. 1 Rome. FAO.

Green, K (1995). Using GIS to predict fire behaviour Journal of Forestry, 93, 2125.

Harga, A. A. (1977). "Soils of Kharga and Dakhla Oases" Geomorphology and classification of some representative profiles. Soil Dept. Desert Inst., Egypt. Bull., 72 (2): 85-97.

Hem, J. D (1985). Study and interpretation of the chemical characteristics of natural water supply. Third edition, U.S. Geol. Surv. Water Supply, paper 2254. Pp. 263.

Hermina, M. (1990). The surroundings of Kharga, Dakhla and Farafra oases. In: Said, R. (Ed) the Geology of Egypt. A.A. Botterdam, Netherlands, pp. 259-292.

Hinton, J. C. (1996). GIS and RS integration for environmental applications. International Journal of Geographical Information Science, 10, 877-890.

ITT (2009). ITT corporation ENVI4.7 software 1133 west chester, while plain, NY, 10604, USA.

Kalogirous (2002). Expert systems and GIS: an application of land suitability evaluation. Comput Environ Urban syst 26: 89-112

Klute, A. (1986). Methods of soil analysis. Part 1. 2nd ed Agron. Monograph No. 9.. ASA and SSSA, Madison, WI.

Lillesand, A. N and R. W. Kiefer (1997). Remote Sensing and image integration $3^{\text {rd }}$ cd. Wily New York.
Mandel, S. and Z. I. Shiftan (1981). Ground water resources, investigation and development, U. S. Academic press, USA.

Munsell (2010). Munsell Soil Color Charts, Baltimore, Maryland, USA.

NCSA (2005). Extracting topographic features from shuttle radar topography mission (SRTM) Images. Technical Report, aig. 05-002 July 18, 2005.

Pieri, C., J. Dumanski, A. Hamblin and A. Young (1995). Land quality indicators. World Bank Discussion papers 315. Washington, USA.

Rajitha, E., C.K. Mukherrjee and R. Vinu Chandrau (2006). Application of remote sensing and GIS for sustainable management of shrimp culture in India. Aquacult Eng. 2006 (36) 1-17.

Rechards, L. A. (1954). Diagnosis and Improvement of Saline and Alkali Soils. USDA, Agricultural Handbook No. 60 p. 102.

Said, R. (2000). The Geology of Egypt. Elsevier publishing Company, New York, U.S.A.

Sharma, R. C., R.K. Sazena and K.S. Verma (2000). Reconnaissance mapping and management of saltaffected soils using satellites images. lut. J Remote sens. 21 (17): 3209-3218.

Shawna, P., J. Byrnes, M. G. Abdelsalam, D. A. Lao Davila, E. A. Atekwana and M. A. Atya (2016): Assessing groundwater accessibility in the Kharga Basin, Egypt: A remote sensing approach. Journal of African Earth Sciences $\times \times \times$ (2016) 1-10.

Soil Survey Staff (1999). Soil Taxonomy: A Basic System of Soil Classification. USDA, Agricultural Handbook No. 436, Washington, D.C. 20402.

Soil Survey Staff (2014). "Keys to Soil Taxonomy" USDA $12^{\text {TH }}$ ED. (USDA, NRCS. Washington, DC.

Soil Science Divison Staff (2017). Soil Survey Manual. USDA Handbook 18. 
Government Printing Office Washington, D.C.

Sys, C.E. and W. Verheye (1978). An attempt to the evaluation of physical land characteristics for irrigation according to the FAO Framework for land evaluation. Into Train course for post grad. Soil, Sci. Univ.

Sys, C., E. VanRanst and J. Debaveye (1991). Land evaluation part 1 and 11 INT. Train-center of post grad. Soil Sci., Univ. Ghent, Agric. Public No.7, Gen. Adm for Dev. Coop., Brussels, Belgium.

Sys, C., E. Van Ranst, J. Debaveye and F. Beernaert (1993). Land evaluation. Part III crop requirements. Agric. pubic. No .7, Gen. Adm for Dev. Coop., Brussels, Belgium.
UNDP/UNESCO (2001). Joint project for the Capacity Building of the Egyptian Geology Survey and Mining Authority and the National Authority for Remote Sensing space Science for the Sustainable Development of the South Valley and Sinai.

World Health Organization "WHO" (1984). International standards for drinking water, 3rd Edition, Vol. 1, Geneva, Switzerland: 130.

Zhongxin, C., Sen Li, R; Jianqiang. P. Gong and M. Zhang (2004). Monitoring and Management of Agriculture with Remote Sensing In. Liang. S (Ed.) Advances in Land Remote Sensing springer, 397-421. 
تقييم الموارد الأرضية والمائية للتنمية الزراعية المستدامة في الواحات الخارجة باستخدام

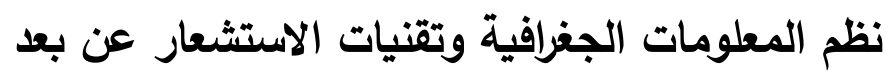

\author{
محمود سليمان محمد
}

معهز بحوث الأراضي والمياه والبيئه - مركز البحوث الزراعية- جيزه

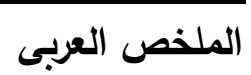

تبذل الدولة جهود كبيرة لإذخال مساحات جديدة من الأراضي الصحراوية في مشاريع التنمية الزراعية لمواجهة

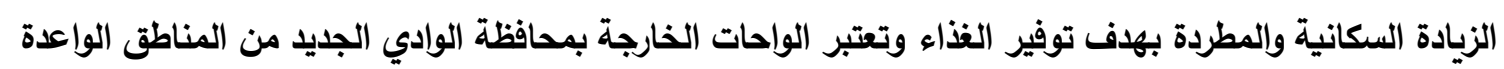

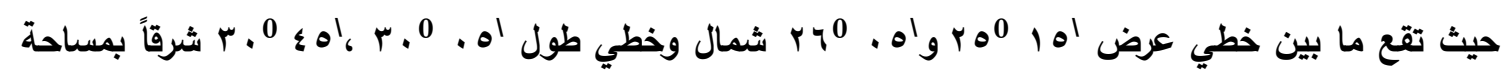

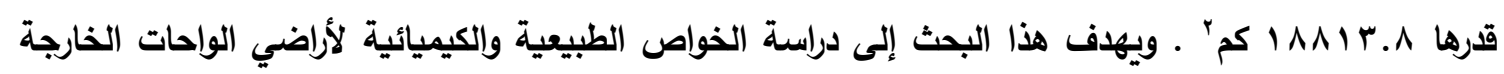

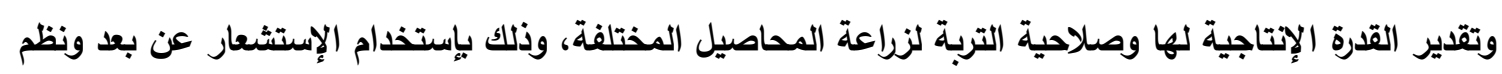
المعلومات الجغرافية.

حيث استخدمت صور القمر الصناعي لآدسات (سنيتال

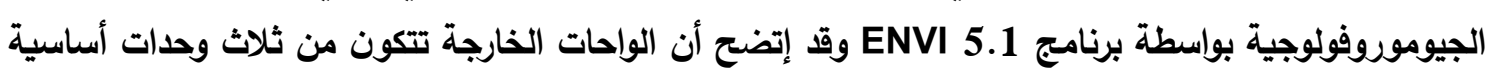

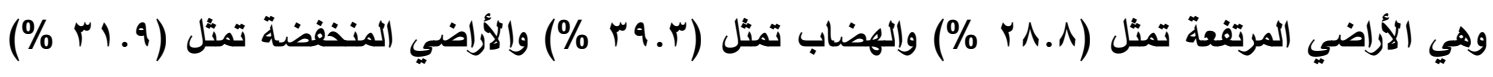
وتعتبر الأراضي المنخفضة من المناطق المناسبة للتنمية الزراعية والتي تختلف في أصلها وإرتفاعها. وقد تم إستخدام نظام التقسيم الأمريكي (USDA,2014) لتقسيم أراضي الواحات الخارجة حتى مستوى العائلات.

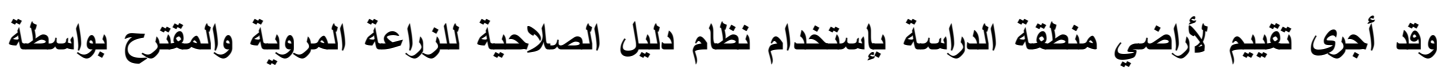
(Sys \& Verheye, 1978) و (1991) وقد وجد أن أراضي منطقة الدراسة تقع تحت درجات

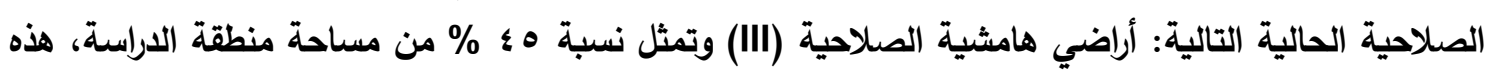

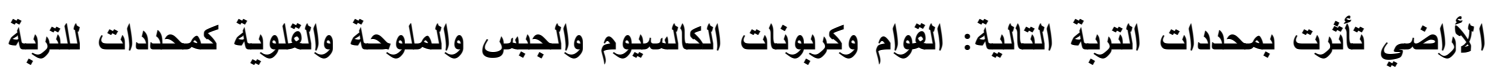

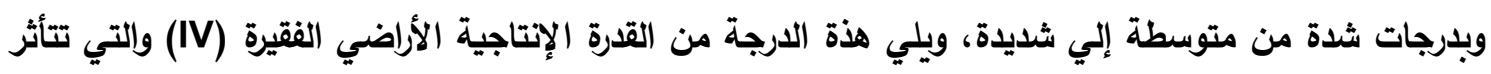

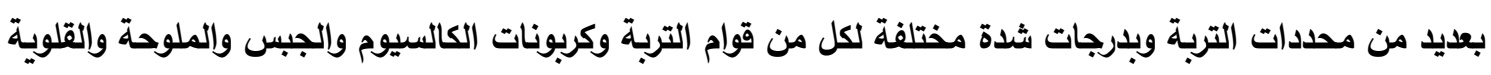

وتمثل هذه الارجة حوالي ه \% من مساحة قطعة الدراسة. وأخيراً الأراضي الغير صاحة (N) والتي تمثل حوالي ه ٪ من من مساحة منطقة الدراسة ومحددات التربة بها لكل

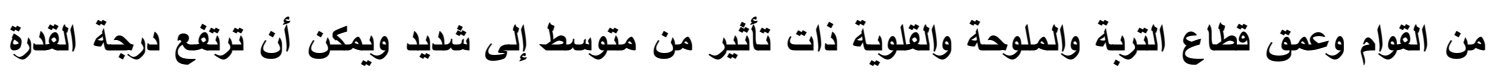
الإتتاجية لهذه الأراضي عن طريق عمليات تحسين التربة فيمكن أن تصبح درجات الصلاحية الكامنة (المستقبلية)

لهذه الأراضي هي: جيدة (III) وهامشية (III) وفقيرة (IV). كما تم تقييم أراضي منطقة الدراسة من حيث ملأمتها لزراعة المحاصيل المختلفة وذلك لتحديد درجة الصلاحية

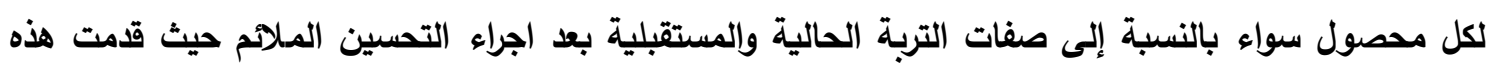


الموائمات بين هذه المحاصيل المختارة في أراضي الواحات الخارجة في صورة جداول لتكون دليلا للإستخدام الأمثل لأراضي منطقة الاراسة.

ولتقيم جودة المياه الجوفية في الواحات الخارجة من خلال التحليلات الكيميائية المختلفة تثير النتائج الى أن

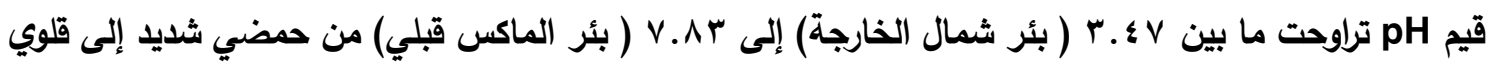

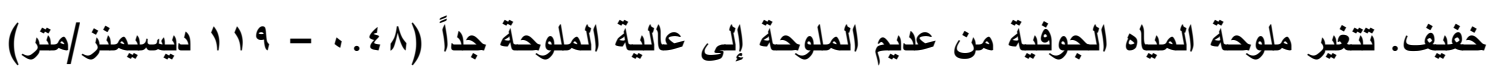

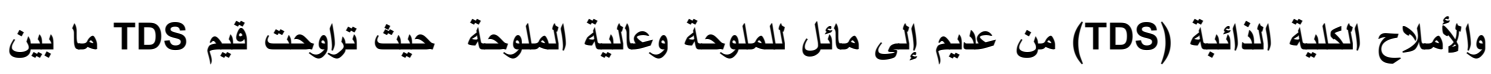

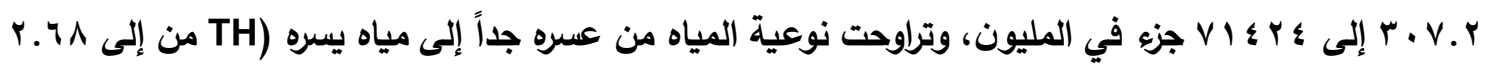

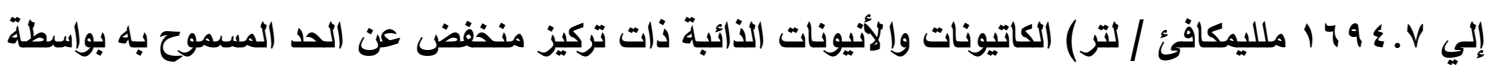

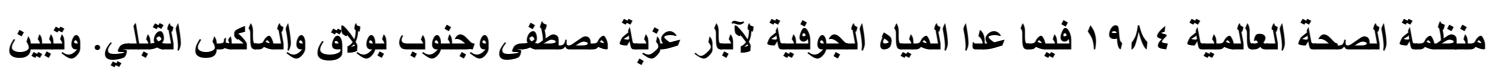

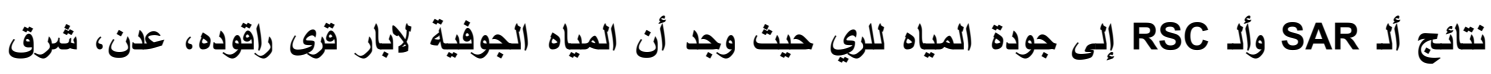
الخارجة تقع في (C2-S1) ( مياه جيده).

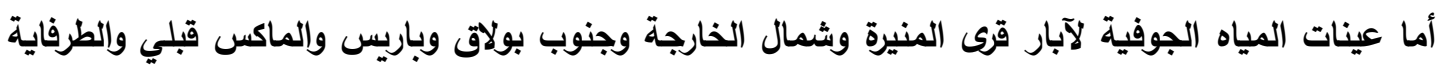

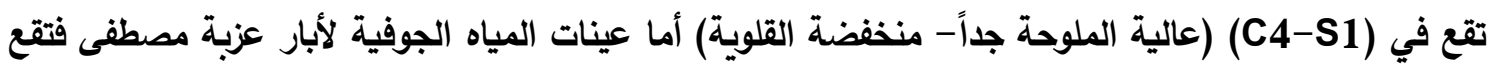
في المجال (C4-S4) ( عالية الملوحة جداً - عالية القلوية جداً). 